\title{
Tropical Amphi-Pacific disjunctions in the Cladocera (Crustacea: Branchiopoda)
}

\author{
Kay VAN DAMME, ${ }^{1 *}$ Artem Y. SINEV ${ }^{2}$ \\ ${ }^{1}$ Environmental Genomics Group, School of Biosciences, University of Birmingham, B15 2TT Edgbaston, Birmingham, UK; \\ ${ }^{2}$ Department of Invertebrate Zoology, Biological Faculty, M.V. Lomonosov Moscow State University, Leninskie Gory, 119991 Moscow, \\ Russia \\ *Corresponding author: kay.vandamme@gmail.com; k.p.vandamme@bham.ac.uk
}

\begin{abstract}
Tropical Amphi-Pacific and trans-Pacific disjunctions are among the most controversial distribution patterns in biogeography. A disjunct distribution pattern between SE Asia (in fact, Indochina-Assam) and the Neotropics is rarely investigated in freshwater invertebrates. In the following, we give the first review on potential tropical Amphi-Pacific disjunctions in the Cladocera (Crustacea: Branchiopoda), a group of freshwater microcrustaceans. As a case study, we examine the littoral-benthic freshwater genus Leydigiopsis Sars, 1901 (Cladocera: Anomopoda: Chydoridae). The lineage has four known species in the Neotropics and we examine the status of Leydigiopsis records from Indochina and Assam (India). Our morphological study shows that the Oriental Leydigiopsis is not a humanmediated introduced species from South America. The populations belong to a distinct species, which we describe as new from Thailand and Vietnam. We discuss the biogeography of Leydigiopsis and examine possible hypotheses underlying the observed distribution pattern (e.g. transoceanic long-distance dispersal, boreotropical migration scenario, African extinction scenario). Our case study shows that a boreotropical origin seems the most plausible scenario for the current distribution of this tropical chydorid lineage. In the absence of a good fossil record, we propose that a comparison with biogeographical hypotheses of plants, may provide useful analogies when studying anomopod biogeography, because ephippia, the propagules for dispersal, functionally act as minute aquatic plant seeds. We list other examples of potential tropical Amphi-or trans-Pacific disjunctions in the Cladocera, based on phenotypes and we provide an updated key to the Leydigiopsis species of the world. Undersampling, taxonomical bias, the absence of molecular data and a poor fossil record, remain the most important obstacles for studying biogeography in non-planktonic tropical freshwater zooplankton.
\end{abstract}

Key words: Cladocera systematics, biogeography, Leydigiopsis pulchra $n$. sp., tropical Amphi-Pacific disjunctions, boreotropics, SE Asia.

Received: March 2013. Accepted: October 2013.

\section{INTRODUCTION}

Studies on intercontinental divergence in ancient lineages with limited dispersal abilities that are specialised to certain habitats are vital to the science of biogeography (Schram, 2008). Tropical disjunctions can be highly informative for historical biogeography and for assessing speciation in any given group of plants or animals, or even for assessing the approximate timing of origin in certain lineages (e.g. Morrone and Crisci, 1995; Morrone, 2001; Sanmartín and Ronquist, 2004). As Löve puts it, it has been demonstrated that distribution areas mirror the history of the species and its evolutionary divergence, making studies of areas and of the variations of the taxa they represent an important tool for those who study the processes of evolution (Löve, 1967). Indeed, biogeographical knowledge allows insights in the evolution of a group: it is knowledge of distributions that may be the most powerful tool for any evolutionary biologist (Grehan, 2007). As our biotas are becoming more globalised, which disturbs the natural distribution patterns, the science of biogeography itself is threatened (Schram, 2008). In SE Asia, biogeographical studies are very important for the continuation of studies on evolution, ecology and conservation in the region (Woodruff, 2010).

\section{The importance of tropical Amphi- and trans-Pacific} distributions

Many examples are known of tropical trans-Pacific and Amphi-Pacific distributions, i.e. of disjunctions between the tropical continental parts of the Neotropics and Australasia. The pattern appeals to the imagination of biogeographers. Southerly trans-Pacific disjunctions are among the most conspicuous and notorious of all known distributional patterns. (McCarthy et al., 2007). Transand Amphi-Pacific disjunctions are often considered old and a result of vicariance, although long-distance dispersal has been proposed as an alternative as well: the biogeographic history of the Southern Hemisphere is considered a prime example of the vicariance scenario: disjunct trans-Pacific distributions resulted from the sequential breakup of the southern supercontinent Gondwana during the last 165 million years (MY), causing 
vicariant division of its ancestral biota (Brundin, 1966; Raven and Axelrod, 1972). Long-distance dispersal is usually discarded as the primary causal explanation of Southern Hemisphere patterns. (Sanmartín and Ronquist, 2004). The latter type of distribution should not be confused with Amphi-Beringian, northern trans-Pacific distributions which are common in freshwater groups (i.e. between East Asia and North America; Bănărescu, 19901995). In fact, we focus here on tropical Amphi-Pacific and trans-Pacific disjunctions. Sometimes the words amphinotic or circum-Antarctic are used for cold-adapted lineages that occur in Australia-New Zealand-South America, but that are not found in Africa or Madagascar (e.g. Winterbourn, 1980; Matile, 1990). The puzzling thing about Amphi- or trans-Pacific disjunctions, is that there is no generally accepted, all-encompassing theory that can explain the pattern. As thrilling and wonderful as trans-Pacific disjunctions might seem to the enthusiastic biogeographer, they might be equally irritating and bizarre to the frowning geologist. Many hypotheses have been suggested to explain trans-Pacific disjunctions, some of which challenge the standard plate tectonic models. This particular discussion is one of the major driving forces in biogeography (e.g. Cox, 1990; Sluys, 1994; Nelson and Ladiges, 2001; McCarthy et al., 2007) and a central theme in panbiogeography (Craw et al., 1999; Grehan, 2007). In panbiogeography, amphi-Pacific organismal distributions form the ingredients of trans-Pacific biogeographic tracks. (Sluys, 1995). Tropical Old-New World divergences fuel the debate of vicariance $v s$ long-distance dispersal (e.g. Sanmartín and Ronquist, 2004; Chen et al., 2013; Christenhusz and Chase, 2013) and are even important for the reconstruction of Gondwana (McCarthy et al., 2007). For example, McCarthy et al. (2007) discuss a long-distance transantarctic dispersal scenario by Brundin (1966), supported by Sanmartín and Ronquist (2004) and discuss animal examples (e.g. Sequiera and Farrell, 2001) while revising the geological background, thereby challenging reconstructions of Gondwana from a biological or biogeographical perspective. In general, for animals, vicariance is considered as the main explanation for this type of disjunctions (Sanmartín and Ronquist, 2004). Since 1988, a number of researchers have compared vicariance vs dispersal explanations for these trans-Pacific disjunctions and have concluded that vicariance should be preferred (McCarthy, 2007). However, under a vicariance paradigm the classical pre-drift reconstruction of Pangea cannot adequately explain transPacific tracks (Sluys, 1995). Hypotheses that are used to explain Amphi- and trans-Pacific disjunctions, comprise lost land connections (van Steenis, 1962) such as the lost continent of Pacifica (Melville, 1966; Nur and Ben-Avraham, 1977; 1982; Kamp, 1980), island arcs (Moores, 1998), island integration (Rotondo et al., 1981), the ex- panding Earth Theory (e.g. Bănărescu, 1990-1995), and alternative models of Gondwana (e.g. trans-Pacific zipper effect; McCarthy, 2003, 2007; Briggs, 2004), ancient transantarctic dispersal (Brundin, 1966; Cracraft, 2001; Sanmartín and Ronquist, 2004), ancient and recent transoceanic long-distance dispersal (e.g. Givnish and Renner, 2004; Keogh et al., 2008; Clayton et al., 2009; Sharma and Giribet, 2012) and general relictualism (Eskov and Golovatch, 1986; Bănărescu, 1990-1995), like the boreotropics hypothesis (Wolfe, 1975; Tiffney, 1985; Morley, 2000, 2001). None of the theories can reconcile the current geological and biogeographical data (Sluys, 1994) and some are highly debated (Cox, 1990; Briggs, 2004). McCarthy et al. (2007) reviewed the historical importance of trans-Pacific disjunctions for biogeography, in particular the disjunctions between Australia/New Zealand and South America, and quoted Brundin (1966): among the problems raised by distribution of plants and animals in the southern hemisphere, there is none which takes a more central position and is more stimulating to the imagination than the problem of transantarctic (transPacific) relationships.

\section{Amphi- and trans-Pacific disjunctions in terrestrial biota}

Numerous disjunctions between the Old and the New World such as Amphi-Pacific and trans-Pacific distribution patterns are known in plant genera, where the extensive fossil record and molecular analysis allow palaeogeographic reconstructions (e.g. Van Steenis, 1962; Heads, 1999; Morley, 2000, 2001; Davis et al., 2002, 2005; Givnish and Renner, 2004; Li et al., 2004, 2011). Most studied examples of trans-Pacific disjunct distributions resulting from oceanic dispersal consist of plant lineages... fewer studied examples of trans-Pacific disjunct taxa are known among animals (Sharma and Giribet, 2012). Yet, not only plant lineages have many examples. Australasian-South American faunal disjunctions have been shown for a wide range of terrestrial taxa (Briggs, 1987; Craw et al., 1999; McCarthy, 2003). These include reptiles (e.g. Gekkonidae, Chelidae, xiphodont crocodiles, iguanas), amphibians (e.g. Leptodactylidae, Hylidae; Tyler, 1979; Cogger and Heatwole, 1981; Tyler et al., 1981), birds (neornithines, galliforms, anseriforms; Cracraft, 2001), marsupial mammals (Beck et al., 2008), fish (e.g. Howes, 1984) and dinosaurs (McCarthy, 2003). The same is true for terrestrial invertebrates. In spiders (Penney and Selden, 2011), the group Micropholcommatinae (Anapidae) is found in Australia, Tasmania, New Zealand, New Caledonia, South America and occurs in fossils in French Cenozoic Amber, as well as the Synotaxidae (Australia and Central and South America and Baltic amber) and the Huttoniidae (extant species in New Zealand, but Cretaceous specimens in Canada; Penney 
and Selden, 2005). Ribeiro and Eterovic (2011) counted an impressive total of 700 species of crane flies (Diptera: Tipulomorpha) belonging to 30 genera and subgenera, that are shared between South America and Australasia. In keropelatid flies, Matile (1990) explored connections between Western North America and SE Asia in the Robsonomyiini and South America-Australia/New Zealand disjunctions (e.g. in the genera Bactrocera Macquart, 1835, Platyroptilon Westwood, 1850, Setostylus Matile, 1990). More examples are known for land planarians (Sluys, 1995), earthworms (Sims, 1980), beetles (Morrone, 1996), moths and butterflies (Grehan, 1991), land snails (Miller and Naranjo-Garcia, 1991), and many others (Briggs, 1987; Craw et al., 1999; McCarthy, 2003).

Famous examples from the animal world with a disjunction between continental SE Asia and South America include the mammal Tapirus Brisson, 1762, with four extant species. Three species occur in the Neotropics and one in SE Asia. The genus is considered to have diverged in the Cenozoic and went extinct in Europe, as shown by fossil and molecular evidence (Ashley et al., 1996). The oldest tapiromorph perissodactyl fossils dated to the lower Eocene (Missiaen and Gingerich, 2012). In the reptiles, the legless lizard family Dibamida has two genera with its centre of diversity in SE Asia (Dibamus Duméril et Bibron, 1839) and a monotypic disjunct genus (Anelytropsis Cope, 1885) in Mexico, the result of a Cenozoic (Eocene) dispersal event (Townsend et al., 2011). Several trans-Pacific (not Amphi-Pacific) disjunctions in animals that include New Zealand and oceanic islands in the Pacific, have received a lot of attention. Sharma and Giribet (2012) studied the colonisation of Pacific islands in a group of trans-Pacific terrestrial arachnids (Zalmoxidae, Opiliones) and discussed a few other animal examples with this type of distribution (e.g. Hackett et al., 2008; Keogh et al., 2008). The authors concluded that the pattern observed for their arachnids resulted from a Late Cretaceous transoceanic dispersal scenario.

\section{Amphi- and trans-Pacific disjunctions in aquatic invertebrates}

For freshwater vertebrates and invertebrates, Bănărescu (1990-1995) studied zoogeographical patterns in detail and listed an impressive number of examples of tropical Amphi-Pacific disjunctions. In the aquatic invertebrates, Cranston examined the disjunct Chironomidae (Diptera) Nandeva Wiedenburg, Reiss et Fittkau, 1998 (Brazil, Patagonia, Central/North Australia), Fissimentum Cranston et Nolte, 1996 (Cranston and Nolte, 1996), Aphroteniella Brundin, 1966, Paraphrotenia Brundin, 1966 (Tasmania and Chile+Patagonia; Brundin, 1966), Botryocladius Cranston et Edward, 1999 (Cranston and Edward, 1999), Pirara Boothroyd et Cranston, 1995 (Cranston, 1999) and others (Cranston, 2000). Mey (1998) noted a relation be- tween the Hydrobiosidae genera Atopsyche Banks, 1905 in South America and Apsilochorema Mey, 1999 in Australasia and in the sister group Rhyacophilidae (Trichoptera), with an assumed origin in Western Gondwana (Strandberg and Johanson, 2010). Also, in other freshwater insects such as mayflies (Ameletopsidae, Coloburiscidae, Nesameletidae, Oniscigastridae), stoneflies (Eustheniidae, Gripopterygidae, Austroperlidae) and in freshwater molluscs, an amphinotic pattern is known (mussels; e.g. Winterbourn, 1980; Briggs, 1987). Bănărescu (1990-1995) attributed such disjunctions to a presumed northern origin of most lineages and their gradual southward spread as one of two main hypotheses for explaining the origin of recent freshwater faunas.

For the smaller epigean tropical freshwater invertebrates, tropical Australasian/South American or SE Asian/South American disjunctions have been given little attention and there are rarely good fossils or molecular data that would provide potential support for the time of divergence. Furthermore, taxonomical uncertainties as well as undersampling remain major obstacles for biogeographical interpretations in small freshwater invertebrates. Better studied are some smaller invertebrate taxa from the subterranean realms, where the Anaspidacea and the Bathynellacea (Crustacea: Syncarida) provide perhaps the best examples of strong disjunctions between southern South America on one side and south-eastern Australia and New Zealand on the other, explained by the Gondwanan transantarctic dispersal scenario (e.g. Stygocaris Noodt, 1963, Atopobathynella Schminke, 1973, Chilibathynella Noodt, 1963) (Schminke, 1974; Lopretto and Morrone, 1998). In the Rotifera, the distribution pattern remains unstudied even though this old group shows typical Gondwana-type disjunctions (e.g. Keratella Bory de St. Vincent, 1827; Segers and De Smet, 2008). Sampling bias and taxonomical confusion in the tropics play an important role, in particular the gap of knowledge regarding the Afrotropical rotifers (H. Segers, personal communication). Among micro-crustacean zooplankton from tropical surface waters (the epigean freshwater Copepoda and Ostracoda), there are few unambiguous examples where the taxonomy is resolved. In Copepoda, several of the ancient disjunct patterns could be artificial and are in fact, intercontinental human-mediated introductions (Reid and Pinto-Coelho, 1994) or result from taxonomical confusion (J. Reid, personal communication), and most are hypogean (e.g. Bryocyclops). Wyngaard et al. (2010) mentioned the absence of tropical Amphi-Pacific disjunctions in Mesocyclops Sars, 1914 (Cyclopidae) clades. Ballast water in boats (now and during long histories of trans-Pacific seafaring) are considered as important vectors, but copepod species also get introduced with aquatic plants or animals in aquaculture (Reid and Pinto-Coelho, 1994). The number of aquatic plant species that have been intro- 
duced in SE Asia from South America through the aquarium trade, is impressive (e.g. Malaysia; Bakar, 2004) and it is very likely that the latter increases the chances for zooplankton introductions. True ancient disjunctions are present in the calanoid Centropagidae genera Boeckella de Guerne et Richard, 1889 and Pseudoboeckella Mrázek, 1901, which show Australian/New Zealand-South American connections (Bayly, 1992). A South American connection has been reported for several harpacticoids from New Zealand as well (Lewis, 1984, 1986). In several subterranean Cyclopoida, a few examples are known, perhaps in the sister genera Anzcyclops Karanovic, Eberhard et Murdoch, 2011 (Australia/New Zealand) and Muscocyclops Kiefer, 1937 (South America) (Karanovic et al., 2011). In freshwater Ostracoda, which have a good fossil record, Gondwanan distributions (including Africa) are common and Amphi-Pacific or trans-Pacific disjunctions do occur but they are rare and have never been named or investigated as such (e.g. Cyprididae, Candonidae) [overview of all ostracod freshwater species and their distributions in Karanovic (2012)]. In the Cyprididae, for example, the genus Riocypris Klie, 1935 has a disjunct distribution between Uruguay and Australia (Karanovic, 2008) and in the ancient family Darwinulidae, the genus Penthesilenula Rossetti et Martens, 1998 has a species that is known only from New Zealand and from Brazil ( $P$. aotearoa; Pinto et al., 2004). In the Notodramididae, the genus Newhamia King, 1855 has four Australian species, one Indian species and two South American species (Karanovic, 2012). Among the larger epigean freshwater crustaceans, Anaspidacea malacostracans also are limited to Australia, Tasmania, New Zealand and Argentina (C. Rogers, personal communication). Amphi- or trans-Pacific disjunctions are unreported in the larger branchiopods. Bănărescu (1990-1995) noted several strongly disjunct distributions in Branchiopoda and Copepoda, which inhabit mainly temporary pools and are able to passively disperse through resistant diapause stages, yet this is relatively outdated. However, molecular research has suggested relatively recent trans-oceanic dispersal events in the large branchiopods between the New World and Australia, based on relatively low genetic divergences (Eocyzicus Daday, 1914; Triops Schrank, 1803; Vanschoenwinkel et al., 2012; Schwenter et al., 2013) and between Australia and Asia (Cyclestheria Sars, 1887; Schwenter et al., 2013). For the crustaceans, that leaves us with a major and widespread component of the freshwater zooplankton: the small branchiopods or Cladocera.

\section{Disjunctions in the Cladocera}

The extant Cladocera, epigean and freshwater in origin, are largely a group of relicts that have undergone a significant number of extinctions over extensive periods of time (Frey, 1986; Korovchinsky, 2006). Cladocerans are an old (Palaeozoic) group and most of the lineages of the taxonomical rank above the species level have retained a number of living fossils, their ancient origins reflected in morphologies and in current distribution patterns (Korovchinsky, 2006; Forró et al., 2008). Because most of the world's extant animal taxa are Cenozoic or younger, and because older lineages can be very informative in studying pre-drift continental positions (Briggs, 2004), the ancient origin of the Cladocera makes it a very useful group for biogeography. The ancient origin has been illustrated by living fossils with peculiar disjunctions, e.g. Pleuroxus smirnovi Kotov, 2008 in the Chydoridae, which Kotov (2008) revealed as an Australian-Central Asian connection. Cladoceran antiquity has been confirmed using molecular methods and the fossil record by Kotov and Taylor (2011), who showed that the split of the Daphnia subgenera dates back to the Mesozoic. There are specialists in different cladoceran lineages and dispersal is mainly limited to freshwater, which are important conditions for assessing a group's biogeographical value (Schram, 2008). However, one of the main obstacles in biogeographical studies of cladocerans is the lack of close morphological and taxonomical investigation as a first step for any further analysis (Kotov, 2008).

The most speciose family, the Chydoridae, is a good example in the Cladocera, where regional endemism, intercontinental divergence and disjunctions have been traditionally studied and an ancient - Palaeozoic - origin has been suggested based on biogeography combined with morphological divergence (non-cosmopolitanism; Frey, 1986, 1987) and later confirmed by molecular analysis (Sacherová and Hebert, 2003). In the absence of an extensive fossil record, the study of historical biogeography and phylogenetic relationships based on the phenotype or the genotype or a combination of both, has become one of the few ways to approach cladoceran evolution and divergence. Disjunctions in the Cladocera are quite common, yet they do not necessarily reflect ancient origins, as the dispersal strategies, as well as the age of origin differ strongly between the cladoceran lineages. As all Cladocera of the Order Anomopoda, the Chydoridae are predominantly restricted to freshwater (but not all). In contrast to ostracods and copepods, Cladocera derive from freshwater ancestors. Anomopoda disperse in the form of dormant embryos encased in ephippia. In fact, ephippia are a main character of the Anomopoda, the largest order within the Cladocera (Fryer, 1987). Cladoceran ephippia contain an embryo in the gastrula stage and the structure can survive unfavourable conditions (periods of drought or cold), can be transported by wind (Cáceres and Soluk, 2002), birds (Proctor, 1964; Figuerola and Green, 2002), mammals (Allen, 2007) and insects (van de Meutter et al., 2008) and form resident egg banks (e.g. Brendonck and De Meester, 2003; Vandeker- 
ckhove et al., 2005a). Chydorids are especially adapted to survive in shallow tropical ephemeral systems such as short-lived pools and marshes, where the dormant community holds a significant diversity that can revive, or be hatched, after dessication (Van Damme and Dumont, 2010). The vacuolate, floating ephippia of the Daphniidae lend themselves to long-distance dispersal (van de Meutter et al., 2008), more so than the compact ephippia of the Chydoridae, which are comparably less mobile as a single unit (Fryer, 1972; Frey, 1987). The ephippia of the Chydoridae, the Macrothricidae and the Acantholeberidae are strongly attached to plants and the substrate when shedded (Scourfield, 1902), aimed at forming resident dormant populations and less adapted for long-distance dispersal (Fryer, 1972). The most likely way for these benthic species to migrate is through passive dispersal of the ephippia by larger animal vectors (e.g. with clumps of mud or plant material). Because of the above differences in strategies and of course a wide range of ages between lineages, old vicariant as well as recent (long-distance dispersal) disjunct scenarios are found in the Cladocera (Frey, 1987; Adamowicz et al., 2009; Kotov and Taylor, 2011). Temperate Old World-New World disjunctions such as Beringian/Atlantic distributions, between the Nearctic and the Palaearctic, can be the result of ancient connections (e.g. Chydoridae; Frey, 1987) or more recent expansions (Quaternary; e.g. Bosmina Baird, 1845; Kotov et al., 2009; Chydorus Leach, 1816) and even of very recent human introductions (e.g. in Daphnia O.F. Müller, 1785; Havel and Medley, 2006: Crease et al., 2012). However, tropical Old World-New World disjunctions in Cladocera are not well known. This can be attributed for a great deal to our limited knowledge in Africa (Van Damme et al., 2013a) and because of a huge gap in molecular data in the non-planktonic Cladocera. As most of the molecular and current biogeographical research concentrates on Daphnia (Adamowicz et al., 2009), a genus which is poorly represented in the tropics when compared to temperate regions (Dumont, 1994), the majority of the Cladocera, which have a large diversity in the tropics (Forró et al., 2008), is ignored. In fact, tropical non-planktonic cladoceran biogeography is only approached by studies on the phenotype (Frey, 1986, 1987). As the group is ancient, a vicariant Gondwana scenario as well as recent dispersal scenarios can be found within different lineages of the same genus and recent long-distance dispersal is not uncommon (Daphnia; Adamowicz et al., 2009). Antitropical disjunctions, between the northern and the southern hemispheres, are thought to reflect an ancient origin (Forró et al., 2008), although temperate elements could theoretically penetrate into the tropics through higher altitudes using sky archipelagoes as cold-water corridors (Van Damme and Eggermont, 2011) or by human introductions. Tropical Amphi-Pacific and trans-Pacific dis- junctions in the Cladocera have never been given close attention, despite their biogeographical potential.

\section{The genus Leydigiopsis Sars, 1901 as a case study in Cladocera biogeography}

One genus, Leydigiopsis Sars, 1901, could become the first case study of a chydorid with a tropical Amphi-Pacific disjunction. During a zooplankton training course at Ghent University (Belgium) in 1996, organised for the cladoceran part by Prof. Em. Dr. H.J. Dumont and colleagues (Prof. N.N. Smirnov and Dr. N.M. Korovchinsky), this peculiar chydorid was told to have been first found in a sample from Indochina by Prof. Dr. L. Sanoamuang (1998), from a locality in North Eastern Thailand (Kalasin province). The record was published in one of the first comprehensive cladoceran species accounts for the country (Sanoamuang, 1998). Only a single specimen was initially found, yet with the increase of sampling and identification efforts in the region (Sinev and Kotov, 2012), the presence of a Leydigiopsis in the Oriental Region, could be confirmed by additional records in Thailand (Maiphae et al., 2005, 2008), Laos (Kotov et al., 2013), Vietnam (Sinev and Korovchinsky, 2013; this study), Cambodia (Tanaka and Ohtaka, 2010) and even in Assam (NE India; Sharma and Sharma, 2007, 2012; as Leydigiopsis curvirostris Sars, 1901). It remained unclear whether these records belong to a Neotropical exotic species, introduced by man, or a valid, yet undescribed SE Asian/Oriental species (Maiphae et al., 2008). As part of sampling campaigns in the South of Thailand in collaboration with Dr. S. Maiphae and P. Sa-ardrit (Prince of Songkla University, Thailand), KVD collected this Leydigiopsis in Natam swamp, providing the Thai specimens for this study. The latter is a diverse locality in Trang province, South Western Thailand, where also other new chydorids were found, belonging to the genera Notoalona Rajapaksa et Fernando, 1987 and Karualona Dumont et Silva-Briano, 2000 (Van Damme et al., 2013b). The Vietnamese specimens were collected by AYS in Cat Tien National Park, Vietnam (Sinev and Korovchinsky, 2013).

The finding of a Leydigiopsis Sars, 1901 in SE Asia is truly remarkable, as this is a typical Neotropical genus. From the above, it is clear that disjunct distributions between New Zealand/Australia and South America in the small freshwater invertebrates occur and might be more common than we think, yet a SE Asian-South American disjunction seems very unusual. Leydigiopsis was first described by Sars (1901) from Brazil and had been considered an endemic genus of the Neotropics, until the discovery by Sanoamuang (1998). Leydigiopsis counts four widely accepted and relatively closely related species (Smirnov, 1971; Sinev, 2004b), several of which can be sympatric (Van Damme and Dumont, 2010). The morphology of L. brevirostris Brehm, 1938 was recently re- 
vised by Valdivia Villar (1984), as well as that of L. curvirostris Sars, 1901 and L. megalops Sars, 1901 by Sinev (2004b) and the remaining L. ornata Daday, 1905 is revised in the current study, together with the unknown Asian populations. The presence of a Leydigiopsis in Indochina could be an indication of an ancient connection (Maiphae et al., 2008), but it could just be a human introduction as well. A revision of these populations was lacking. The genus has a conspicuous phenotype and in general appearance it can hardly be mistaken for another chydorid, save perhaps by the untrained observer with Leydigia Kurz, 1875, Parvalona Van Damme, Kotov et Dumont, 2005 or species of the Alona quadrangularis (O.F. Müller, 1776)-complex, to which it parallels in morphology because of similar littoral/benthic feeding habits (Van Damme et al., 2005; Van Damme and Dumont, 2010). Though similar in appearance to the latter taxa, this is a result of convergence of the chydorid benthic model with a laterally flattened body, increased exopodite surfaces and well developed spines (Fryer, 1968; Kotov, 2006). Leydigiopsis is no doubt a benthic specialist, confirmed by its morphology as well as by live observations (Sars, 1901; Van Damme and Dumont, 2010). A more detailed look at the morphology of Leydigiopsis and in particular at its limb characters, has revealed that it is actually closer to the genera Euryalona Sars, 1901 and Tretocephala Frey, 1965, which might have separated relatively early from the main trend in the Aloninae (Sinev, 2004b; Van Damme et al., 2013b) and is related closest of all to a monotypic sister genus in Australia, Miralona Sinev, 2004 (Sinev, 2004a). In Southern Thailand, Leydigiopsis appears to be one of the paludal species, very rare and restricted to swamps, which are relict habitats in SE Asia with an ancient history, harbouring an underestimated diversity among the Cladocera (Van Damme et al., 2013b).

\section{Purpose of this study}

In the following, we describe the morphology of the SE Asian/Oriental Leydigiopsis sp. and we explore whether this is an exotic Neotropical species or a species in its own right. We provide a redescription on the Neotropical $L$. ornata, its closest relative. We discuss the possibility of tropical Amphi-Pacific disjunctions in the Cladocera listing known examples, and we compare disjunctions and biogeographical scenarios in order to investigate the distribution pattern that we observe in Leydigiopsis.

\section{METHODS}

In Vietnam, samples were collected with a standard plankton net and dip net and preserved in $75 \%$ ethanol or $3 \%$ formaldehyde. Animals were selected from the sample under a binocular stereoscopic microscope MBI-10 placed on slides (in a drop of a glycerol-ethanol mixture), and studied under Olympus compound microscopes CX-41 and CX-51 (Olympus, Tokyo, Japan). Dissections were conducted by electrolytically sharpened tungsten needles. Measurements were conducted using an eyepiece-micrometer. Drawings were made by means of a drawing tube or camera lucida.

\section{RESULTS}

\section{Taxonomic account}

\section{Family Chydoridae Dybowski et Grochowski, 1894}

Subfamily Aloninae Dybowski et Grochowski, 1894 emend. Frey, 1967

\section{Genus Leydigiopsis Sars, 1901}

Type species: Leydigiopsis curvirostris Sars, 1901 (Brazil). Leydigiopsis pulchra $\mathrm{n}$. sp.

Leydigiella indica Daday (nomen nudum) in E. von Daday, unpublished manuscript. Leydigiopsis sp.: Sanoamuang (1998); Maiphae et al. (2008); Korovchinsky (2013); Kotov et al. (2013); Van Damme et al. (2013b); Sinev and Korovchinsky (2013). Leydigiopsis curvirostris: Sharma and Sharma (2007). Leydigionopsis sp.: Tanaka and Ohtaka (2010).

Etymology: the epithet pulchra, meaning beautiful (feminine form), is a reference to this fair species. At the same time, we dedicate this new taxon to Prof. Dr. L. Sanoamuang (Maha Sarakham University, Thailand), the first to have discovered this species in 1996 (Sanoamuang, 1998) and whose contributions to the Thai zooplankton studies - and therefore, to limnology in SE Asia - have been remarkable. Prof. Dr Sanoamuang's first name, Laorsri, originally means the same as the Latin word pulchra: beautiful girl, fair lady. It is the second chydorid recently dedicated to Prof. Dr. Sanoamuang, after Anthalona sanoamuangae (Sinev and Kotov, 2012).

Type locality: Natam swamp, Trang province, western coast of southern Thailand, coordinates $07^{\circ} 37.029^{\prime} \mathrm{N}$, 99³3.628'E (Van Damme et al., 2013b).

Type material: THAILAND. We examined fifteen adult parthenogenetic females. All material deposited at the Princess Maha Chakri Sirindhorn Natural History Museum (PSUNHM), Faculty of Science, Prince of Songkla University, Thailand. HOLOTYPE: an adult parthenogenetic female in a sealed $70 \%$ ethanol with glycerol tube from Natam swamp, Trang province, western coast of southern Thailand, coordinates $07^{\circ} 37.029^{\prime} \mathrm{N}$, 99 33.628'E, Coll. by K. Van Damme, S. Maiphae and P. Sa-ardrit, 9.IV.2000. Accession number PSUZC-PK100401, labeled as Leydigiopsis pulchra sp.nov., one parthenogenetic female from Natam swamp, Trang province, South Thailand HOLOTYPE. PARATYPES: five complete adult parthenogenetic females, same data as holo- 
type, in a tube with $70 \%$ ethanol and glycerol. Accession number PSUZC-P1004-02.

Additional material: additional specimens from Thailand are deposited under the latter accession number (PSUZC-P1004-20). VIETNAM. Over 40 parthenogenetic females from a small forest lake near Bau Sau lake, Cat Tien National Park, Dong Nai province, $11^{\circ} 27.178^{\prime}$ N, $107^{\circ} 20.328^{\prime}$ E, 05.2009, coll. by A.Y. Sinev, three parthenogenetic from the same location, 10.IV.2009, by A.Y. Sinev, in the personal collection (AYS) at Moscow State University.

\section{Description of the adult parthenogenetic females -} Thai specimens (Figs. 1-4)

Habitus (Fig. 1A). Length, 0.65-0.72 mm, average $0.68 \mathrm{~mm}(\mathrm{n}=10$, adults). Colour in life, reddish to dark brown. Body 1.45 times as long as high, height ca. 0.5 $\mathrm{mm}$. Body shape ovoid in lateral view, strongly bilaterally flattened in dorsal view, with strongly convex posterior margin and no clear posterodorsal corner; the latter relatively high (Fig. 1A). Dorsum evenly convex, maximum height of body at the middle (Fig. 1A). No dorsal keel.

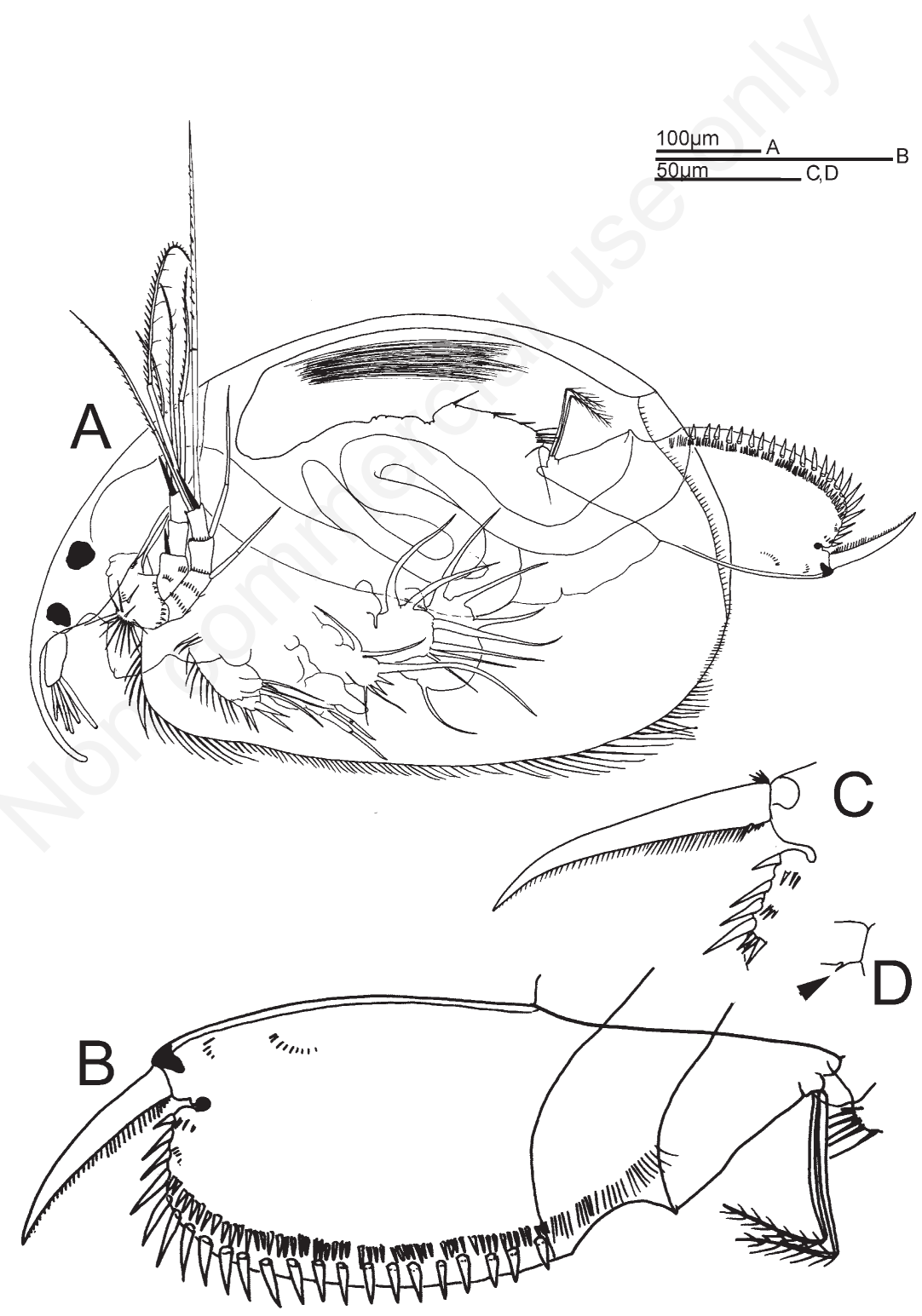

Fig. 1. Leydigiopsis pulchra n. sp., adult parthenogenetic female from Natam swamp, Trang province, Southern Thailand, coll. April 2000 by K. Van Damme, S. Maiphae and P. Sa-ardrit. A) Habitus, lateral view; B) postabdomen, lateral view; C) terminal claw; D) basal spine on terminal claw (pecten and basal spinules omitted; arrow indicates small basal spine). 
Ventral carapace margin is straight. The posteroventral corner of the valves (Fig. 1A) is broadly rounded, not distinct and with fine spiniform setules not arranged in clusters (Figs. 1A and 2H). Ornamentation see under Carapace.

Head. The head is low and with a very clear prolonged rostrum (Fig. 1A). The rostrum is curved inwards and is at least 2.0-2.5 times as long as the antennules (without aesthetascs; it also reaches beyond the length of the aesthetascs). Ocellus and eye of similar size, ocellus some- times just smaller (Fig. 1A). In dorsal view, (Fig. 2B) the rostrum takes up about one sixth of the headshield (from apex of rostrum to posterior margin). The lateral margins of the headshield (Fig. 2B) are straight, the posterior portion (beyond connection with the mandibles) is about a third of the total length of the headshield. Posterior margin broadly blunt (Fig. 2B). Head pores (Fig. 2C) as for the genus, a wide slit with sclerotised margins. Small lateral pores about equidistant between midline and margins (not visible in Fig. 2B, but they are present - see also in Fig.

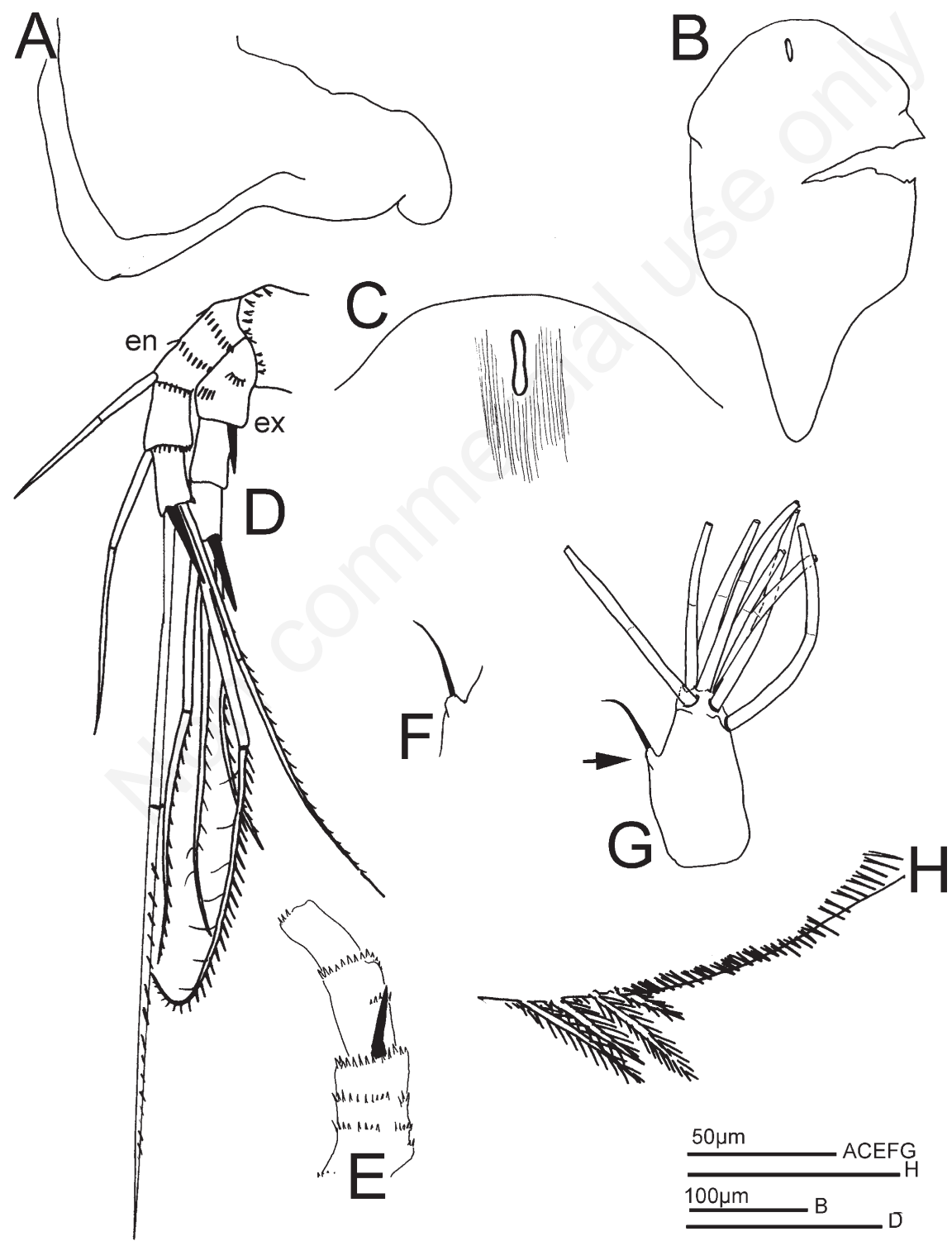

Fig. 2. Leydigiopsis pulchra n. sp., adult parthenogenetic female from Natam swamp, Trang province, Southern Thailand, coll. April 2000 by K. Van Damme, S. Maiphae and P. Sa-ardrit. A) Labral keel, lateral view; B) headshield, dorsal view; C) headshield, posterior portion, showing main headpore and fine striation (small pores not shown); D) second antenna; E) idem, exopod spine on first segment; F) first antenna, accessory seta and projection; G) first antenna (arrow on projection); H) posteroventral valve corner. en, exopod; ex, exopod. 
5F). Main head pores close to the head shield margin, about once or just less than once the distance between the two main head pores.

Carapace. No wide striation or hexagons, just very dense fine striation pattern, on carapace (Fig. 1A) as well as headshield (Fig. 2C). Marginal setae about 85 (Fig. 1A), in three distinct groups, first one on frontal margin continuing along anterior ventral margin and reaching to about one sixth of the margin, these setae relatively long, followed by the median group, that reaches to about two thirds of the ventral margin, all these setae short, about half to a third of the previous group. Final, posterior, group of setae about one third of the margin, longest (longer than anterior group) and decreasing gradually in size towards the posteroventral corner (which is not defined, and no notch present). Beyond the last setae, continuous row of spinules/spiniform setae, continuing in a wide curve towards the posterodorsal corner.

Labrum (Fig. 2A) rather short (Fig. 1A) and with a relatively straight margin of the keel. rather short and round. Ventrally rather angular, but not with a sharp tip. Small lip with gently protruding tip can be present (Fig. 1A) as for the genus, but it is not strongly pronounced.

Antennules (Fig. 2F and 2G). Not reaching apex of rostrum. About two times as long as wide (but mostly shorter, about 1.8 times as long as wide in Fig. 2G). Lower half wide and rectangular, distal half narrowing (Fig. 2G). No setules on the corm observed under light microscopy (but could be present). Sensory seta implanted about halfway from the apex, on a clear strong projection (Fig. $2 \mathrm{G})$. Aesthetascs, six terminal and three subapical/lateral aesthetascs. One (lowest) aesthetasc always curved. Three subapical aesthetascs relatively longer, the five apical aesthetascs of similar size.

Second antennae (Figs. 1A and 2D) with exopodite longer than endopodite (by about half the length of the ultimate exopod segment). Spinal formula (en/ex) 001/101, setal formula 113/003. Basal segment of the antennae with a tuft of very long setules (Fig. 1A). The first endopodite seta thick and spiniform, reaching beyond the ultimate segment of the endopod (Fig. 2D), the second endopodite seta also spiniform and thick, and longer than the length of complete endopodite. First exopodite spine long, between just over half (Fig. 2E) to just shorter than the second exopodite segment (Fig. 2D). Terminal (apical) spines on both antennal branches are strongly developed, long, more than the segments on which they are implanted (Fig. 2D). Both are of similar lengths. The terminal setae all long, one terminal endopodite seta thicker than the others and longer (Figs. 1A and 2D).

Postabdomen (Fig. 1B-D) short and wide, deepest around the middle of the postanal portion. Length about 2-2.5 times as long as wide. Deep incision in distal portion, just under the terminal claw (Fig. 1B and 1C) (the gap is clearly closed). Ventral margin (up in Fig. 1B) gently convex, dorsal margin straight, to weakly convex, length about three times the anal margin. The anal margin itself is very short and deeply concave, with well demarked preanal and postanal corners, but not protruding or projecting. Postabdominal armature. The postanal margin has strong singular teeth, not grouped, and very well developed, that go all the way up to the ventralmost point of the distal margin (just below the terminal claw base that is). The postanal margin counts about 24 large teeth (Fig. 1B). Distal teeth longest, not curved, gradually decreasing to about half the size towards the anal margin. Lateral fascicles form an almost continuous row, each group consisting of about three strong, short stout teeth. Within each group, the distalmost denticle is not strongly enlarged (therefore it is hard to separate the groups that are close; Fig. 1B) and the groups consist of more teeth (more than five) near the anal margin. The lateral fascicles or teeth do not reach beyond the postanal margin. In total, about 13-14 lateral groups (lateral fascicles), or about 50 spines in total. No marginal teeth on the anal margin, and lateral fascicles appear almost as one row of fine setules (in fact, 3-4 groups). On the ventral portion of the postabdomen, there are a few small rows of denticles. Near the basis of the terminal claw there is a strong distal (ventral) sclerotisation. Terminal claw (Fig. 1B-D). Longer than the anal margin (about 1.75 times as long) and quite straight. Proximal and distal dorsal pectens different, setules in proximal pecten twice as long as in distal pecten (Fig. 1C). There is a minute basal spine present, with basal spinules (Fig. 1C). When seen without setules, it is about four times smaller than the claw thickness at the base (Fig. 1D) and situated at some distance from the base of the claw.

First maxilla not studied.

First limb (Fig. 3A-D). Epipodite short, kidneyshaped (Fig. 3A). First endite with two long apical setae (Fig. 3A) and one long anterior seta at the division between the first and the second endites (shown black in Fig. $3 \mathrm{~A})$. On the second endite, three setae, with two distinctly longer and a third of about half this length and two small anterior elements at its basis; a sensilla-like seta that is long, naked and blunt, was missed here during description and is shown in Fig. 5M for the Vietnamese population. The third endite with four typical setae of similar lengths. Outer distal lobe with long fine seta, serrulated in the distal half (Fig. 3B) and with a peculiar projection with basal long setules near its basis (Fig. 3C). The outer distal lobe (ODL) has a minute projection (reduced seta?) near the basis of the ODL seta (Fig. 3C). The inner distal lobe (IDL) (Fig. 3B and 3D) has three setae of which two longer (not as long as IDL seta), of scraper-like morphology, unilaterally armed with strong setules in their distal halves. The third (smallest) seta is about half the size of the smallest scraper-like setae, and has no armature (at 
least not seen under light microscope). Ejector hooks slender (not shown in figures). Anterior row of setules not continuous but four groups of 3-4 setules in the proximal margin (Fig. 3A, long setules down on right side; limb is shown upside down), and then singular setules in distal part (Fig. 3A). Gnathobase not studied.

Second limb (Fig. 3E and 3F). Exopodite long and without a seta, instead with long setules towards and on the apex. Endites with eight scrapers, of which the first is conspicuously long, about 1.3 times longer than the second scraper; from the third scraper towards the gnathobase, their lengths gradually decrease, but the last two scrapers of similar sizes (Fig. 3E). No elements seen on the secondary row (no reduced setae observed, only

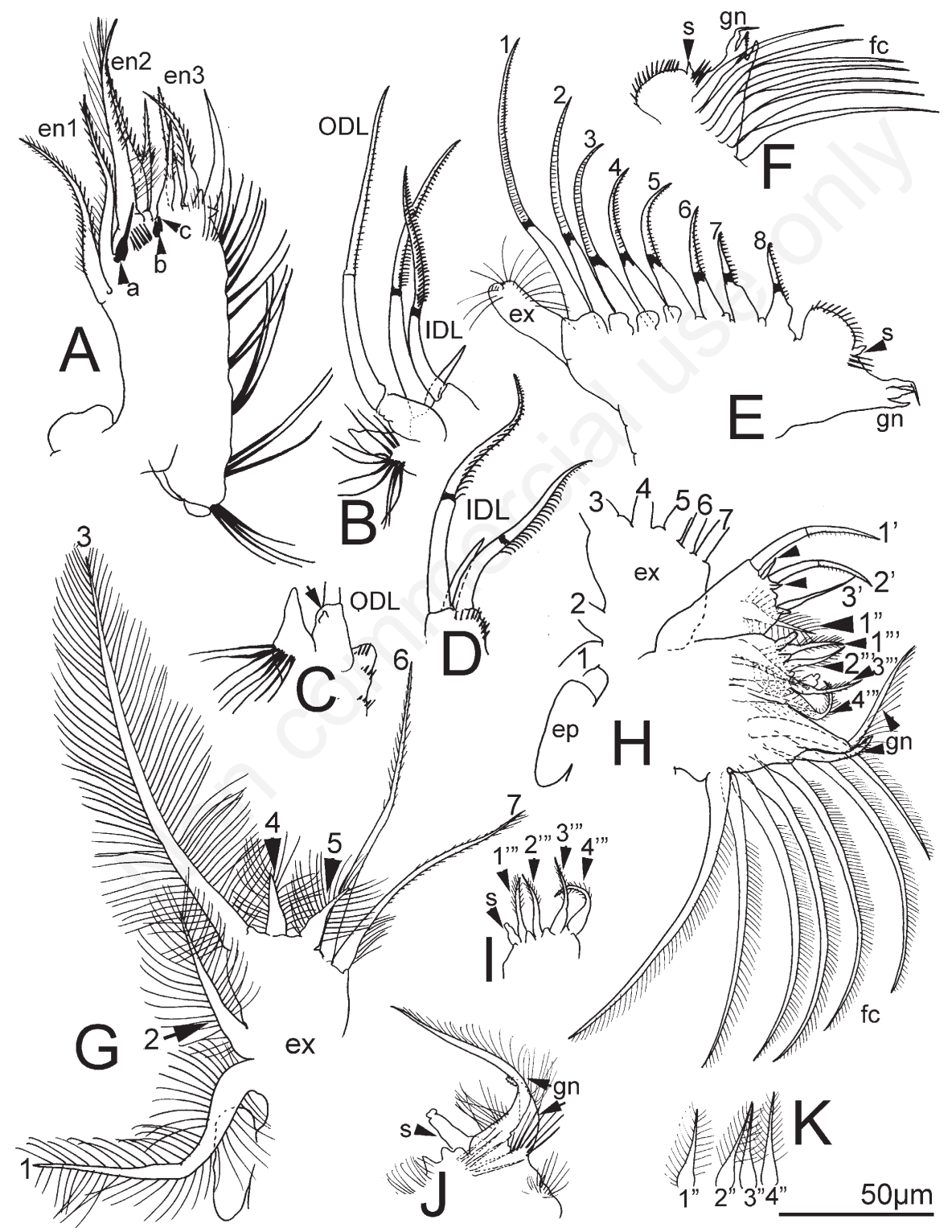

Fig. 3. Leydigiopsis pulchra n. sp., adult parthenogenetic female from Natam swamp, Trang province, Southern Thailand, coll. April 2000 by K. Van Damme, S. Maiphae and P. Sa-ardrit. A) First limb (ejector hooks not shown; a-c indicate the anterior elements on endites); B) idem, ODL and IDL; C) idem, basis ODL (arrow indicates element basal to ODL seta); D) IDL setae; E) second limb (without filter comb; 1-8 indicate numbers for scrapers); F) idem, gnathobase; G) third limb (numbers 1-7 refer to the exopodite setae); H) idem, endites (numbers refer to inner and outer endite setae); I) idem, outer portion (outer endite setae numbered 1"'-4"'); J) idem, gnathobase; K) idem, setae inner portion (inner endite setae numbered 1"-4"). en, endopodite; ODL, outer distal lobe; IDL, inner distal lobe; ex, exopodite; gn, gnathobase; s, sensillum; fc, filter comb; ep, epipodite. 
the scales). Gnathobase with a setulated tuft and a sensillum, followed by three elements on an elevated basis and seven gnathobasic setae in the filter plate, of which the first two just a little shorter than the following ones (but just shorter by a tenth, not more).

Third limb (Fig. 3G-K). Epipodite elongated, oval and without projections; exopodite (Fig. 3G) with rectangular to quadrangular corm and setae in $2+5$ arrangement. The first seta is very long and thick, and bent, and 1.5 times the length of the second seta (in V-arrangement). The third exopodite seta is almost three times (2.8 times in Fig. 3G) the length of the second, fourth and fifth setae short and rather conical, sixth and seventh fine and long, about half the thickness of the previous setae (Fig. 3G); the latter setae are of similar lengths (seventh just shorter) and about five times as long as the short conical setae (fourth and fifth). All setae plumose except for last two, which are armed with fine short setules in their distal halves. Endites (Fig. 3H-K): three setae on external endite (1'-3'; Fig. $3 \mathrm{H}$ ), of which first two rather slender, long and curved, setulated in distal halves, and reduced, small elements between them (three elements). Four plumose setae (1"-4" in Fig. 3K) on the inner side and internal endite with four shorter setae with small setules in distal halves (1"'-4"' in Fig. 3I) and one small naked element (Fig. 3I, small naked element on the left). The gnathobase (Fig. 3J) has a long bottle-like sensillum, a long, bent seta with a shorter blunt seta near its basis that it is just less than twice the length of the former (also seen in Fig. 3H). Gnathobasic filter comb with seven well developed long setae, of which the first is just shorter (Fig. 3H).

Fourth limb (Fig. 4A and 4B). Epipodite rounded rectangular, with a small fingerlike projection (not reaching the centre; Fig. 4B). Exopodite quite rectangular, with six setae. First two setae of similar lengths and as long as the fourth, third longer (1.3 times as long as fourth). Third to sixth actually gradually decreasing in size, where the fifth and the sixth setae are very thin (half the thickness of previous setae). The last seta (sixth) is about a third in length of the third seta (Fig. 4B). First two setae widely plumose, third and fourth setae with shorter setules (longer in basal half), fifth and sixth setae thin and with very short setules in distal halves. Endite with four marginal setae (1'-4') of which the first with plump basis and relatively narrow distal part with minute setules (unilateral setulation), followed by three flaming torch setae which are long but with typically thicker basis (2'-4' in Fig. 4A) and followed by an elongate receptor. On the inner side, three well developed plumose setae (Fig. 4A). Gnathobase as for genus, with bent seta and basal naked element, and five long filter setae (not shown).

Fifth limb (Fig. 4C). Pre-epipodite with two tufts of setules (small incision in middle), epipodite small and completely round, without projection. First three setae long and decreasing gradually in size, fourth seta more slender and shorter. First three setae plumose, last seta with short setules, strongly convex margin between third and fourth setae. Inner lobe broadly diamond-shaped and with apical setules, followed by two inner setae (1'-2') and two inner elements, of which the second minute (Fig. 4C). No filter comb.

Sixth limb. Absent.

Male and Ephippial female: unknown.

Note on the Vietnamese specimens of $L$. pulchra n. sp. (Fig. 5)

Populations of L. pulchra n. sp. from Vietnam (Fig. 5), correspond to the same species as the Thai population, but small differences can be noted. The material is now too limited to make a decision whether this is variability (no males for example), and we consider this for now as one species. The habitus is similar in size and the animal has the same long rostrum (Fig. 5A-C), which is tapering distally in dorsal view and relatively narrow (Fig. 5D and 5E). In females of the first juvenile instar the length was 0.50-0.53 and height $0.30-0.33 \mathrm{~mm}(\mathrm{~N}=6)$; in females of second juvenile instar length was $0.62-0.63$ and height $0.39 \mathrm{~mm}(\mathrm{~N}=3)$. In adult females (Fig. 5A-C) length was $0.70-0.75$ and height $0.45-0.49 \mathrm{~mm}(\mathrm{~N}=11)$. Ocellus and eye are of the same size of each other, yet smaller than in the Thai population. The rostrum is 2.5 times as long as the first antenna (Fig. 5B), and the body 1.55-1.6 times as long as it is high (Fig. 5A). Ventral valve setae up to 80 in total. The headshield is largely as in Thai population, yet somewhat more narrow (Fig. 5D and 5E). Headpores with one long narrow slit with chitinised margin and two adjacent small pores, close to the midline (Fig. 5F). The first antennal endopod seta is relatively shorter than in the Thai population, in the Vietnamese specimens it is not reaching over the last segment of the endopod (Fig. 5B and 5C). Postabdomen (Fig. 5I and 5J) with postanal portion about three times the anal portion and with about 19-20 marginal teeth in the postanal portion, the distalmost slightly longer (but not two to three times longer than the median teeth). Anal margin not as deeply concave as in the Thai specimens (Fig. 5I and 5J). Dorsal distal portion might protrude a bit (Fig. 5J) and the ventral margin can be slightly convex. Labral keel triangular (Fig. 5G and $5 \mathrm{H}$ ) with small indentation possible near the tip (Fig. 5G) and no setulation observed. First maxilla with two well developed thick setae with setules in distal halves and tuft of setules at the base (Fig. 5K). First limb similar (ejector hooks different in length; Fig. $5 \mathrm{~N}$ ). On the anterior side of first limb, on the second endite, there is a long anterior blunt sensilla-like seta (Fig. 5M, arrow) that was overlooked in the Thai population during description.

Distribution and biology: Leydigiopsis pulchra n. sp. is known from Northeastern India (Assam; Sharma and Sharma, 2007, 2012) and Indochina, where it has been re- 
ported from Cambodia (Tanaka and Ohtaka, 2010), Laos (Kotov et al., 2013), Thailand (Sanoamuang, 1998; Maiphae et al., 2008), Myanmar (unpublished note by E. von Daday) and Vietnam (Sinev and Korovchinsky, 2013). In SE Asia, the species has not been reported from Sundaland or Wallacea. It is unknown from southern India (e.g. Kerala, Western ghats) (Chatterjee et al., 2013). We predict that more records will appear in the region now that the species is formally described and that it can be recognised. It is currently considered as a single taxon, but regarding the wide range of L. pulchra $\mathrm{n}$. sp. and the fragmentation of its habitat, more than one species could be expected. We noted small differences between the Southern Thai and the Vietnamese populations, which might indicate speciation. The Assam records (Sharma and Sharma, 2007, 2012) fall under the general external morphology for this species, yet remain unrevised. Found in shallow swamps, such as Natam swamp in Trang

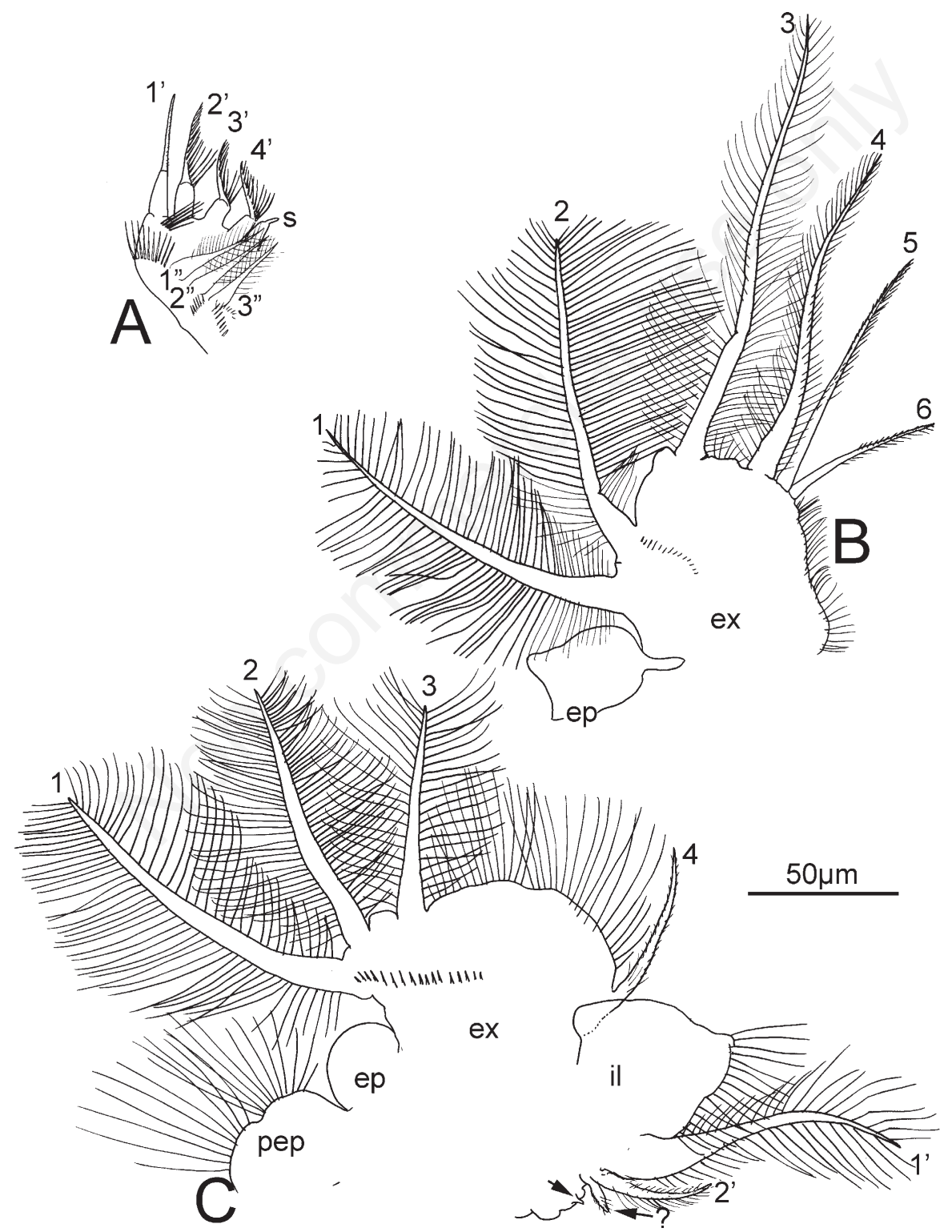

Fig. 4. Leydigiopsis pulchra n. sp., adult parthenogenetic female from Natam swamp, Trang province, Southern Thailand, coll. April 2000 by K. Van Damme, S. Maiphae and P. Sa-ardrit. A) Fourth limb, endite (flaming torch setae 1'-4', inner setae 1'-3"); B) fourth limb, exopodite (setae numbered 1-6); C) fifth limb (exopodite setae numbered 1-4; inner portion setae numbered 1'-2'; arrow points at element/setae with unclear homology, same for question mark; both are gnathobasic elements). s, sensillum; ep, epipodite; ex, exopodite; pep, pre-epipodite; il, inner lobe. 
province (Van Damme et al., 2013b). In Vietnam, L. pulchra $\mathrm{n}$. sp. was found in a relatively shallow forest pond bordered with swamps, in humic water. The bottom of the pond was covered by dead leaves and was covered by Salvinia Séguier, 1785 on the surface; for details on the habitat and the cladoceran community, see Sinev and Korovchinsky (2013).

Differential diagnosis: Leydigiopsis pulchra $\mathrm{n}$. $\mathrm{sp}$. is easily recognised from all other species in the genus by the short postanal portion and the short distal marginal teeth on the postabdomen, and by the labral plate with blunt apex. The rostrum is long, 2-2.5 times as long as the first antenna (longer than in L. brevirostris and L. ornata) but shorter than in L. curvirostris.

\section{Note on the Indian Leydigiopsis populations}

In the illustrations, Sharma and Sharma (2007) depict Leydigiopsis curvirostris specimens as having a very long

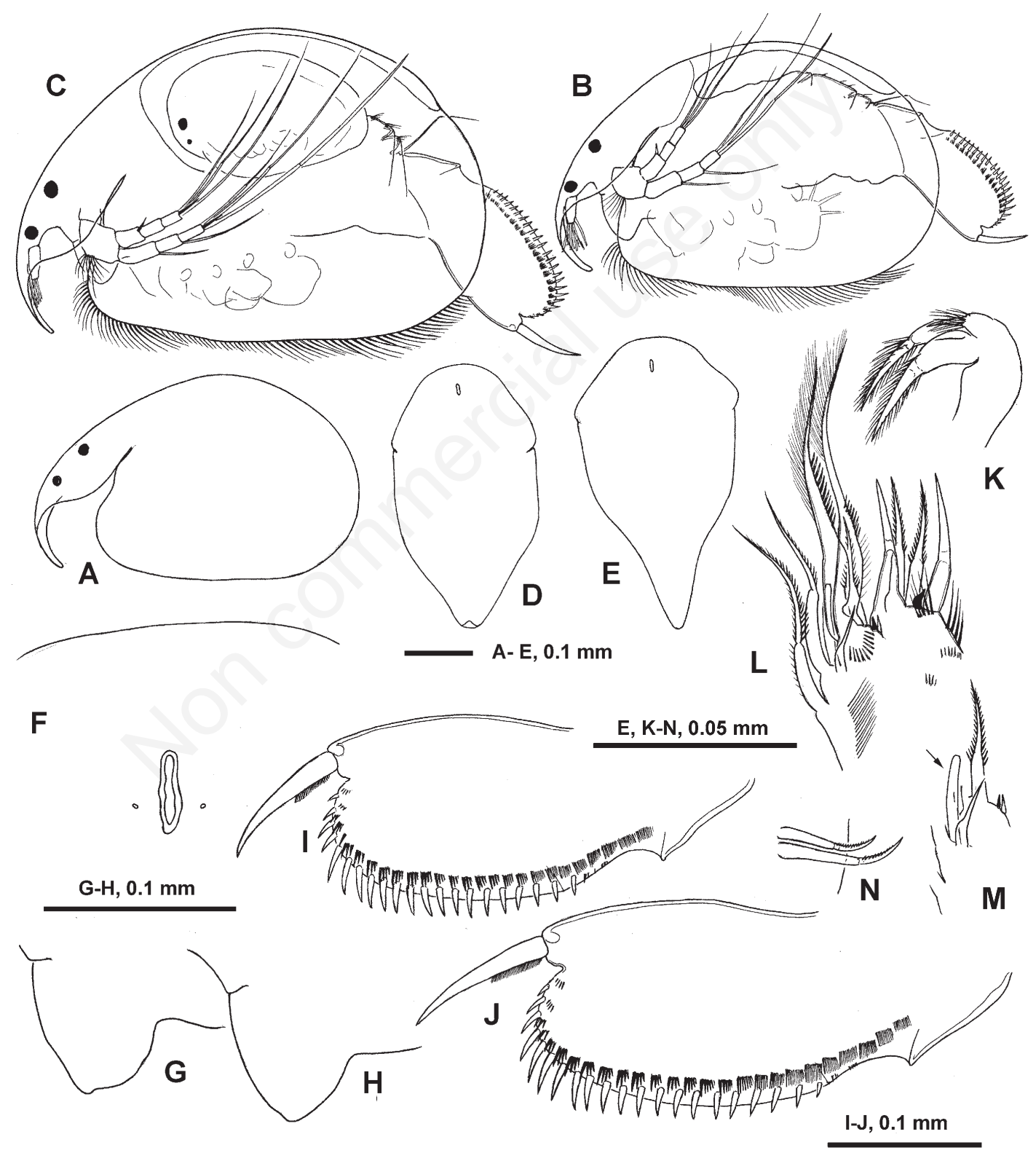

Fig. 5. Leydigiopsis pulchra n. sp. from a small forest lake near Bau Sau lake, Cat Tien National park, Dong Nai province, Vietnam, coll. May 2009 by A.Y. Sinev. A, B) Juvenile female; C-M) adult parthenogenetic female. A) instar I, outline; B) instar II, habitus; C) habitus; D, E) headshield; F) headpores; G, H) labral keel; I, J) postabdomen; K) first maxilla; L) first limb, distal setae of endites 1-3; M) idem, second endite, additional anterior blunt seta (arrow); N) ejector hooks. 
rostrum. Photographs in a later publication by the same authors (Sharma and Sharma, 2012) from the same population, clearly show a shorter rostrum. Both in the drawings and in the photographs of this animal, Sharma and Sharma $(2007,2012)$ show a postabdomen with short marginal spines, which to us confirms that this is similar to the Indochina populations of L. pulchra n. sp. As we noted for the Vietnamese vs Thai population, differences may be present, therefore we do not exclude potential cryptic speciation, especially considering that these might be relict populations in a strongly fragmented habitat.

\section{On Leydigiella indica Daday (nomen nudum)}

During the revision of this paper, A.A. Kotov remarked that E. von Daday, in an unpublished manuscript on India in the early $20^{\text {th }}$ century, aimed to describe Leydigiella indica Daday, yet he died before he could complete his paper. Indeed, a specimen of Daday's taxon is kept at the Hungarian Natural History Museum and corresponds to Leydigiopsis. According to the latter authors, the origin of the specimen is India or., lac. Kawkareik, Tenasserim (D XVII-72; II/P-722). Kawkareik is the capital of Kawkareik district, Kayin State (the Kawkareik pass goes through the Tenasserim hills in southern Myanmar). By 1824 a small part of Burma, and by 1886 two thirds of Burma were part of British India, which lasted until 1937. So, during the time of Daday, who published between 1883 and 1911, Kayin State in Myanmar, was considered a part of British India. Kawkareik is adjacent to northern Thailand, relatively close to the border. Daday's Leydigiella indica is a nomen nudum and has therefore no priority, yet Daday's record can be considered as the first of L. pulchra n. sp. in the region. The record falls within the expected distribution range of this species in South East (SE) Asia.

\section{Redescription of Leydigiopsis ornata Daday, 1905}

\section{Specimens examined}

Twenty-six parthenogenetic and juvenile female from Charco 6, Jonuta-Villahermosa, Tabasco state, Mexico, N 1758.766', W 92 14.150 ', coll. by Alexey A. Kotov, from personal collection of A. A. Kotov, AAK 2001-036, A.N. Severtsov Institute of Ecology and Evolution. This Mexican population, serving for a basic redescription here, was earlier mentioned in Elías-Gutiérrez et al. (2006).

\section{Adult parthenogenetic females (Figs. 6-8)}

Habitus (Fig. 6A-C). In females of the first juvenile instar, length was 0.43-0.45 and height 0.27-0.30 mm ( $\mathrm{n}=3)$; in females of second juvenile instar, length was 0.51-0.60 and height $0.33-0.34 \mathrm{~mm}(\mathrm{n}=8)$. In adult females length $0.63-0.73$ and height $0.46-0.51 \mathrm{~mm}$. Colour in life, brown- ish. Body 1.65 times as long as high. Body shape ovoid in lateral view and bilaterally flattened in dorsal view and no dorsal keel, as for the genus. Dorsum quite convex, maximum height of body at the middle (Fig. 6A) and the ventral valve margin not completely straight, but with deeper point just anterior of the middle (Fig. 6A). The posteroventral corner of the valves (Fig. 6C) is broadly rounded, but with a clear notch (Fig. 6C). Ornamentation is a very fine striation, see also below under carapace.

Head. Rostrum about two times as long as the antennule, not more (Fig. 6C) and gently curved inwards. Ocellus just smaller than the eye, and situated at about 1.3 times as far from the rostral apex as from the eye (Fig. 6C). The headshield is about two times as long as wide and the rostrum is about a fifth of the total headshield length. Posterior margin rounded (Fig. 6F). Head pores (Fig. 6F and 6G) as for the genus, this long pore about five times as long as wide and with small pores very close to it (Fig. 6G). The main head pore is about two times as far from the posterior headshield margin as the length of the pore itself.

Carapace. Marginal setae more than 100 (Fig. 6D), in four distinct groups (one anterior short group, one long anteroventral group, one short anteroventral group near the middle and one long medioventral to posterior group, which is more continuous and where setae decrease in size posteriorly). As mentioned above, a notch at the posteroventral corner is clearly present (Fig. 6D).

Postabdomen (Figs. 6I and 6J) quite long, deepest in the distal half of the postanal portion. At least 2.5 times as long as wide. Incision in distal portion, just under the terminal claw, is moderate (Fig. 6J). Ventral margin gently (Fig. 6H) to strongly (Fig. 6I) convex, dorsal postanal margin quite straight, length more than three times (up to 3.5 times) the anal margin. The anal margin itself is very short and deeply concave, almost semi-circular, with well demarked corners, of which preanal corner projects just slightly. Postabdominal armature. As in previous species, but distal marginal teeth conspicuously larger than the others (Fig. 6I). The postanal margin counts about 17-18 large teeth (Fig. 6H and 6I) and about four posterodistal teeth (just below the claw base). Lateral fascicles in groups of four-five well developed spines each, of which the distalmost is clearly thicker. In the distal groups, these spines reach beyond the dorsal margin (Fig. 6J). About 18 lateral fascicles in the postanal portion, continuing into about four groups in the anal portion (Fig. 6H and 6I). The anal margin lacks marginal teeth. Small rows of denticles on lateral portion near ventral margin (Fig. 6H). Terminal claw (Fig. 6J). As in previous species, longer than the anal margin (about 1.73 times) and straight except for the tip. Pectens (Fig. 6J) as in previous species. Basal spine very small and merged from different spinules and therefore impossible to distinguish (in fact, a merged group). The 
basal spine/spinules short (base of the claw is about 2.6 times as long as the basal spine), and situated at some distance from the basis, and there is a space between the start of the proximal pecten and the basal spines.

Labrum (Fig. 7A-C) triangular, keel with relatively straight margin (Fig. 7A and 7C), sometimes a bit angular (Fig. 7B). The tip is rather acute and protruding (Fig. 7AC). No setulation.

Antennules (Fig. 8A). As in previous species, but the sensory seta, implanted just above the middle of the an-

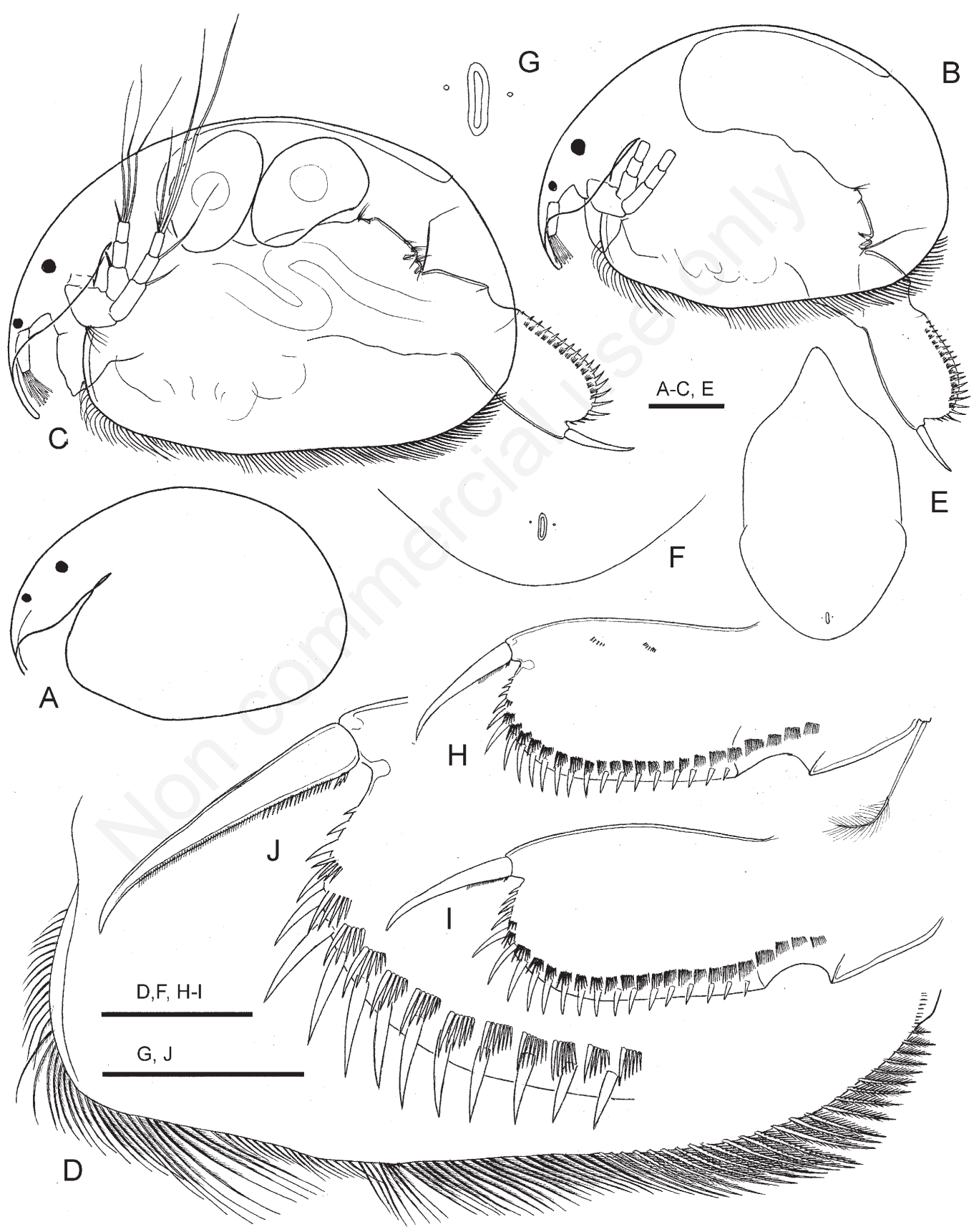

Fig. 6. Leydigiopsis ornata Daday, 1905 from Charco 6, Jonuta-Villahermosa, Tabasco state, Mexico, coll. 11.01.1998 by Alexey A. Kotov. A, B) Juvenile female; C-J) adult parthenogenetic female; A) instar I, outline; B) instar II, habitus; C) habitus; D) carapace margin and setae; E) headshield; F) posterior margin of headshield, with headpores; G) headpores; H, I) postabdomen; J) terminal claw and distal portion of postabdomen. Scale bars: $0.1 \mathrm{~mm}(\mathrm{~A}-\mathrm{F})$ and $0.05 \mathrm{~mm}(\mathrm{G}, \mathrm{J})$. 


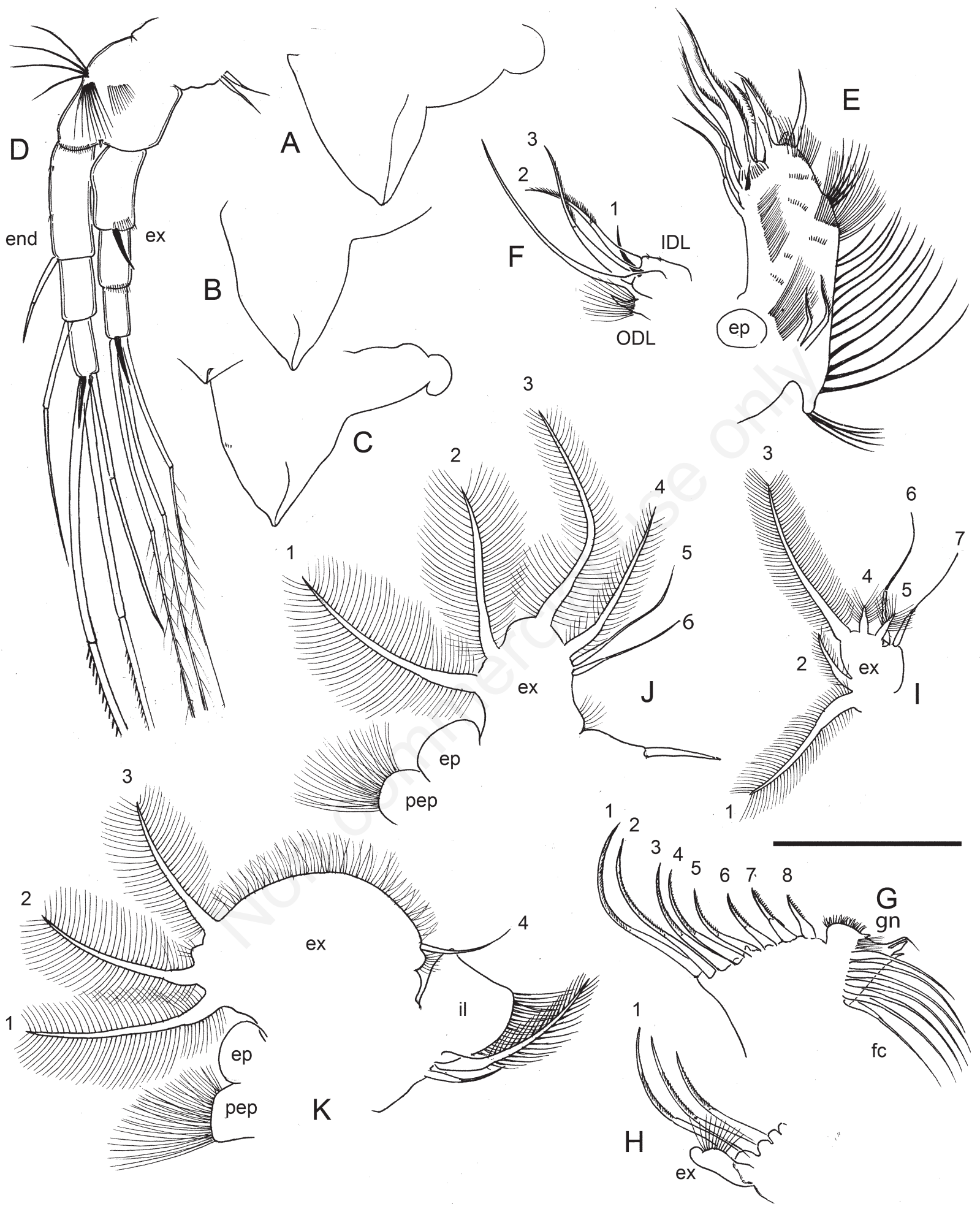

Fig. 7. Leydigiopsis ornata Daday, 1905, adult parthenogenetic females from Charco 6, Jonuta-Villahermosa, Tabasco state, Mexico, coll. 11.01.1998 by Alexey A. Kotov. A-C) Labral keel; D) second antenna; E) first limb; F) idem, IDL and ODL (with numbering of IDL setae 1-3); G) second limb (scrapers numbered 1-8); H) idem, exopodite and first three scrapers (first numbered); I) third limb (exopodite setae numbered 1-7); J) fourth limb (exopodite setae numbered 1-6); K) fifth limb (exopodite setae numbered 1-4). end, endopod; ex, exopod; ep, epipodite; IDL, inner distal lobe; ODL, outer distal lobeend, endopod; gn, gnathobase; fc, filter comb; pep, pre-epipodite; il, inner lobe. Scale bar: $0.1 \mathrm{~mm}$. 
tennule, is relatively short (the width of the antennular corm at the point of implantation is about 1.6 times as much). Three thicker subapical/lateral aesthetascs.

Second antennae (Fig. 7D) same as in the previous species, but the first endopodite seta is short, little longer than the middle segment of the endopodite and the terminal (apical) spines on both the antennal branches are shorter, only just longer than the terminal segments themselves. Exopodite clearly longer than the endopodite, by about half the length of the last endopodite segment.

First maxilla (Fig. 8B) with three setae, of which two thick and well developed, setulated in the terminal halves, and a third, shorter by half, setulated from base to tip.

First limb (Fig. 7E and 7F). Epipodite round (Fig. 7E). First endite (Fig. 8C) with the typical two long apical setae, second endite with three setae of which two long. There are two anterior elements where the bases of en1en2 meet (labeled $s$ and $a$ in Fig. 8C). The long blunt naked seta (s) here is more than twice the length of basal anterior seta. The third endite has four setae and a sensillum as well (the $s$ on the left in Fig. 8C), and at the basis of the joint of second and third endites, there is a small anterior seta ( $b$ in Fig. 8C). Outer distal lobe (Fig. 7F) implanted with long setae around a hillock and a long seta. The inner distal lobe (IDL) has two longer setae of similar lengths (labeled as 2,3 in Fig. 7F) and one smaller seta, half as long ( 1 in Fig. 7F). Ejector hooks of different sizes (Fig. 7E). Anterior row with about 12 single setules, and then in a distal cluster of setules Gnathobase not studied.

Second limb (Fig. 7G and 7H). Exopodite relatively elongate (Fig. $7 \mathrm{H}$ ), not reaching half the length of the first scraper and with long setules instead of a seta. The endites and gnathobase are as in the previous species (Fig. 7G).

Third limb (Fig. 7I, 8D, 8E). As in the previous species, but exopodite seta 1 is longer by about $2 / 3$ the length of seta 3. The endites (Fig. 8E and 8D) are as in previous species. All sensillae could be seen for this species (Fig. 8E).
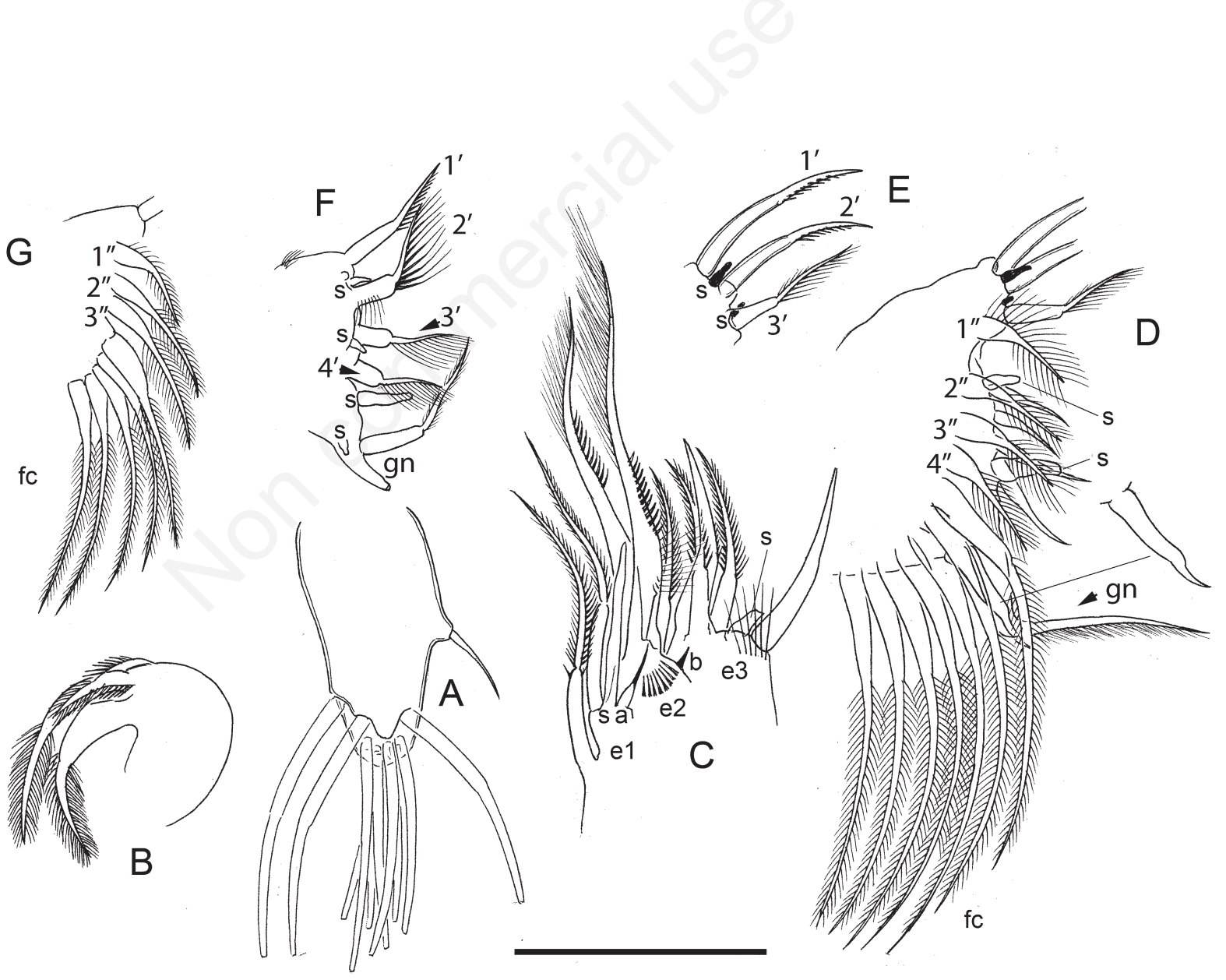

Fig. 8. Leydigiopsis ornata Daday, 1905, adult parthenogenetic females from Charco 6, Jonuta-Villahermosa, Tabasco state, Mexico, coll. 11.01.1998 by Alexey A. Kotov. A) First antenna; B) first maxilla; C) first limb, distal portion with setae of endites 1-3 (elements labelled a-b); D) third limb, endite setae (endite setae numbered 1"-4"); E) idem, inner setae (labelled 1'-3'); F) fourth limb, endite with flaming torch setae (1'-4') and sensillae; G) idem, inner setae (1"-3") on endite and filter comb. e1-e3, endites 1-3; s, sensillum; gn, gnathobase; fc, filter comb. Scale bars: $0.05 \mathrm{~mm}$. 
Fourth limb (Figs. 7J, 8F, 8G). Pre-epipodite and epipodite round, the latter without projection. The limb is the same as in previous species, but the exopodite corm is less wide and the third and sixth exopodite setae are relatively longer (but differences are minimal). In the endites (Fig. 8F and 8G), small sensillae were observed near the bases of flaming torch setae 2' and 3' (Fig. 8F). The three inner setae and filter comb (Fig. 8G) are as in previous species, although setae 2 " and 3" are relatively more slender.

Fifth limb (Fig. 7K). As in previous species, but the exopodite corm is larger, and the margin between third and fourth exopodite setae is more convex and expanded, as for other species in the genus (Fig. 7K). No inner elements were found near the inner setae (1'-2').

Sixth limb. Absent.

Differential diagnosis: the Neotropical L. ornata has a rostrum of about two times as long as the antennule (the rostrum is mostly longer in L. pulchra $\mathrm{n}$. sp.) and it has a relatively elongate postabdomen with a long postanal portion, the total postabdomen length being about 2.5 times as long as wide. It differs clearly from L. megalops in having a normal ocellus and from $L$. curvirostris in the shorter rostrum (Sinev, 2004a, 2004b; Van Damme and Dumont, 2010). The seta on the first endopodite segment of the second antenna is barely longer than the second segment; in L. pulchra $\mathrm{n}$. sp. it reaches at least the end of the final en- dopodite segment. Like all other South American species of the genus, $L$. ornata has a labral plate with an acute tip, while in L. pulchra n. sp. it is blunt and rounded.

Distribution and biology: the distribution of $L$. ornata (and all other species of Leydigiopsis), is presented in Fig. 9 (see Discussion). Not much is known about its biology, except that it seems to follow the same ecology and biology that are typical for the genus, being mud-dwelling species that can withstand highly ephemeric systems and dystrophic conditions (Van Damme and Dumont, 2010). A previous record of $L$. brevirostris from Tabasco state of Mexico (Elías-Guttiérez et al., 2001) in fact belongs to L. ornata.

\section{South American-Southeast Asian/Australian affinities in the Cladocera}

We list examples of all records in the Cladocera of species and species groups where closest affinities are found between the South American and the SE Asian representatives of a lineage, including taxonomically unrevised records.

\section{Taxonomically revised records}

\section{Alona dentifera (Sars, 1901) - Alona siamensis Sinev} et Sanoamuang, 2007 (Chydoridae)

A. dentifera is a Neotropical species that has recently been revised, distributed from the South of the USA to

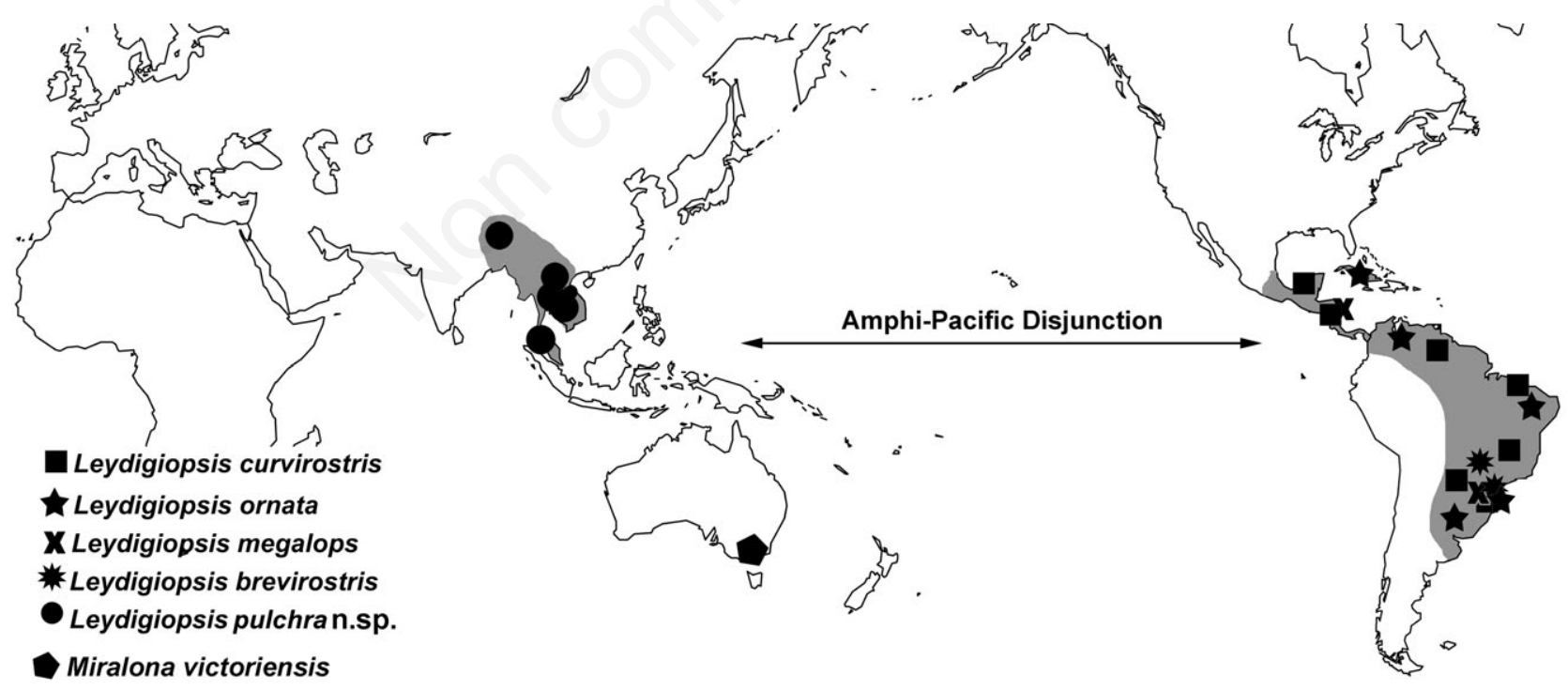

Fig. 9. Distribution of the genus Leydigiopsis Sars, 1901. The genus counts four species in South America and one in Indochina and Assam (India). The sister genus, Miralona, is included in the map (Australia). Distribution points for Miralona after Sinev (2004a) and for the four Neotropical species after records by Sars (1901), Daday (1905), Brehm (1937), Valdivia Villar (1984), Rey and Vasquez (1986a, 1986b), Smirnov (1988), Zoppi de Roa and Vasquez (1991), Elías-Gutiérrez et al. (2001), Hollwedel et al. (2003), Serafim et al. (2003), Sinev (2004b), Elías-Guttiérez and Varela (2009), Güntzel et al. (2010), Van Damme and Dumont (2010), Rocha et al. (2011), and Rocha Sousa and Elmoor-Loureiro (2013). For L. pulchra n. sp., records after Sanoamuang (1998), Sharma and Sharma (2007, 2012), Maiphae et al. (2008), Tanaka and Ohtaka (2010), Kotov et al. (2013), and Sinev and Korovchinsky (2013). 
Argentina (Sinev et al., 2004). Southeast Asian records of $A$. dentifera have been assigned to the second species in this small lineage, $A$. siamensis, hitherto found in Thailand and Malaysia only (Idris and Fernando, 1981; Sinev and Sanoamuang, 2007). Both species form a small lineage that is not of genus level but of species group level and does not belong to Alona. It is a small group that is much closer to (or part of?) Coronatella and still needs formal separation (Van Damme and Dumont, 2008a). No records of the $A$. dentifera-type are known from other regions than the Neotropics and SE Asia since 1901, even though the external features are conspicuous [body shape, the long basal spine on terminal claw and the denticle(s) on the posteroventral corner]. Not much is known about the ecology of these animals, except that they prefer shallow, vegetated water bodies and temporary pools (Sinev et al., 2004; Sinev and Sanoamuang, 2007).

\section{Alona yara Sinev et Elmoor-Loureiro, 2010 - Alona kotovi Sinev, 2012 (Chydoridae)}

A. kotovi Sinev, 2012 is a species of the A. quadrangularis group, recently described from Vietnam, with a wider distribution in SE Asia and in the Oriental region (Sinev, 2012). In the northern portion of East Asia, e.g. in South Korea, closely related populations occur, yet females as well as males show distinct differences (K. Van Damme, personal observation), so A. kotovi could be more restricted in its distribution in Eastern Asia. In the Palaearctic, it is replaced by true A. quadrangularis. Within the A. quadrangularis group of Alona, a lineage of the Aloninae that is morphologically quite distinct (Van Damme and Dumont, 2008b), the SE Asian A. kotovi is closest to the Brazilian A. yara (Sinev, 2012). These are species from macrophyte-rich shallow water conditions, although they can occur in a wide range of habitats (Sinev, 2012; Sinev and Elmoor-Loureiro, 2010).

\section{Leydigiopsis Sars, 1901 (Chydoridae)}

This study - Leydigiopsis is a tropical Amphi-Pacific disjunct genus with four species in the Neotropics and a single species in Indochina and Assam, described herein (L. pulchra n. sp.).

\section{Macrothrix sioli Smirnov, 1982 - Macrothrix pholpunthini Kotov, Maiphae et Sanoamuang, 2005 (Macrothricidae)}

In the genus Macrothrix, which still needs proper revision, there are only four species with a distinct large spine-like projection on the posterodorsal corner of the carapace; their relationships are confirmed by phylogenetically relevant morphological characters (e.g. limbs) (Kotov et al., 2005): M. sioli, M. malaysiensis, M. pholpunthini and $M$. brandorffi form a group together with M. odiosa and M. paulensis (Iheringula Sars, 1900; Kotov et al., 2005). Of this branch in Macrothrix, M. sioli and $M$. pholpunthini are distinctly closest, as shown by a phylogenetic analysis based on 12 morphological characters by Kotov et al. (2005). M. sioli, described from Brazil, is distributed in the Neotropics, M. pholpunthini is only known from Thailand so far (Kotov et al., 2005).

\section{Taxonomically unrevised records}

A number of unrevised/unnamed Australasian taxa exist, of which the closest Neotropical relative is defined and no other tropical records are known. The only taxa mentioned are those whose identification can be trusted.

Chydoridae: two species in Ephemeroporus Frey, 1982 exist with only Neotropical-Oriental records: E. hybridus (Daday, 1905) and E. tridentatus (Bergamin, 1939) (e.g. Maiphae et al., 2008). These records of Ephemeroporus species in SE Asia require revision.

Chydoridae: a yet undescribed Oxyurella cf. longicaudis (Birge, 1910) is just recently recorded from Laos (Kotov et al., 2013). Oxyurella longicaudis is a purely Neotropical species, with quite conspicuous morphology (Van Damme and Dumont, 2010) that can hardly be confused when compared to the common representative of this genus in SE Asia, O. singalensis Daday, 1898, and in fact with any other species in the genus. The finding of an Oxyurella cf. longicaudis in Laos is quite remarkable, and this record should be revised.

Chydoridae: an example of a trans-Pacific distribution, not of an Amphi-Pacific disjunction, is Alona setigera Brehm, 1931. The only species with two headpores in the A. costata-group (Sinev, 2008) and therefore easily recognisable, A. setigera is distributed in Indonesia, Australia, Tasmania, New Zealand (Sinev, 1999) and in the Pacific oceanic islands (Schabetsberger et al., 2009). Morphologically identical populations (at least for the basic characters) have been found in Brazil (Santos-Wisniewsky et al., 2001) and remain to be revised. The same can be said for Camptocercus australis Sars, 1896.

Macrothricidae: Streblocerus pygmaeus Sars, 1901 is a widespread Neotropical species, found in shallow waters, mainly in swamps (Van Damme and Dumont, 2010). Records of $S$. pygmaeus in SE Asia, most likely a close undescribed sibling, are found in similar pond or swamp environments (Sanoamuang, 1998; Maiphae et al., 2008; Van Damme et al., 2013b). This record needs revision. Some Oriental populations that have been described earlier as $S$. pygmaeus, were placed in $S$. inexpectatus Smirnov, 1992 (Idris and Fernando, 1981), yet there are undoubtedly S. pygmaeus-type populations present in Thailand (Van Damme et al., 2013b; A.A. Kotov, personal observation) which future revisions will likely reveal as a separate species.

Macrothricidae: Pseudomoina lemnae (King, 1853) is 
distributed in the Neotropics and Australia, but it is unknown from Africa.

Sididae: Sarsilatona serricaudata (Sars, 1901) is a species from the Neotropics and the southernmost part of the USA, yet with records from SE Asia (e.g. Maiphae et al., 2008) and the same has been suggested for Pseudosida ramosa (Daday, 1905), mentioned from Thailand (Sanoamuang, 1998). Both records need further revision. Sarsilatona cf. fernandoi (Rane, 1983) has recently been described from Vietnam for SE Asian records of S. serricaudata (Korovchinksy, 2011), the latter being a Neotropical species. Both are the most closely related within the lineage (Korovchinsky, 2011), so this can be considered another example of a link. Most likely $P$. ramosa is a misidentification (Korovchinsky and Sanoamuang, 2008).

Some records could be misleading because of a lack of taxonomical resolution or misidentifications, and are approached here with more care.

Macrothricidae: Macrothrix flabelligera Smirnov, 1992 is recorded from Australia, Neotropics and the Oriental zone, but it is most likely not a true biogeographical link. The $M$. flabelligera records outside Australia are most likely M. triserialis Brady, 1866 or M. elegans Sars, 1901 with additional spine-like setules on the branches of the second antennae, too often used as a diagnostic character (A.A. Kotov, personal communication).

\section{DISCUSSION}

\section{Amphi-Pacific disjunction in Leydigiopsis}

Four species of the tropical stenothermic genus Leydigiopsis are known from South America (L. megalops, L. curvirostris, L. brevirostris and L. ornata) and we have hereby described a fifth species, found in Indochina and Assam (L. pulchra n. sp.). The distribution of Leydigiopsis is shown in Fig. 9. The map also includes Miralona victoriensis Sinev, 2004 from Australia, a monotypic sister genus (Sinev, 2004a). All species, except for L. brevirostris, have been taxonomically revised and are well-defined [Miralona in Sinev (2004b), L. curvirostris and L. megalops in Sinev (2004b), L. brevirostris in Valdivia Villar (1984), L. ornata and L. pulchra n. sp. in this study]. The new species is distinctly different and cannot be confused with other Leydigiopsis because of the combination of a short postabdomen, a long rostrum and long setae on the first antennal endopod segment. We can rule out taxonomical uncertainties for Leydigiopsis, recently having revised the other species (Sinev, 2004b). Limb characters are strongly conserved in this genus and we noted main differences in morphology of the postabdomen, antenna and head.

With largest diversity in South America and a disjunction with SE Asia, the genus Leydigiopsis does not follow a common biogeographical pattern for Cladocera. Distri- butions overlap in Brazil, which is the centre of diversity of this genus. Most tropical/subtropical cladoceran genera either have a circumtropical distribution, with a few centres of endemism besides many monotypical genera, especially in the chydorids (e.g. Australia; Korovchinsky, 2006; Forró et al., 2008). A strongly disjunct pattern between South America and southern tropical Asia in a single cladoceran genus is unknown, except now for Leydigiopsis. For other animal groups, South AmericanAustralian/New Zealand disjunctions are more common (see Introduction), but they usually do not involve Indochina. Even though it is the only cladoceran genus with this distribution, Leydigiopsis might not be the only cladoceran lineage with an Amphi-Pacific disjunction. We have identified three more cases of recently described SE Asian species where the closest sibling can be found in the Neotropics and another nine cases where SE Asian records have not been formally revised, but where cryptic species have been suggested and where an Amphi- or trans-Pacific disjunction is possible.

One of the examples is the pair Alona dentifera- $A$. siamensis (Coronatella), two close species that form a phenotypically distinct group in the subfamily, the first a well-known South American endemic (Sinev et al., 2004), the second extremely rare in SE Asia and described just recently (Sinev and Sanoamuang, 2007). Both have been revised recently and no representatives of the small $A$. dentifera-lineage are known from other former Gondwana fragments. In Macrothrix, the Neotropical M. sioli forms a close morphological group with the SE Asian $M$. polpunthini, which is a recent discovery as well (Kotov and Hollwedel, 2004; Kotov et al., 2005). Among the potential examples from different cladoceran families (Chydoridae, Macrothricidae and the Sididae), Alona setigera seems the only cladoceran so far with a trans-Pacific distribution, connecting Brazil to Australia. This species is quite distinct within the $A$. costata-group, so there is little doubt that these records belong to the $A$. setigera-phenotype, but it is unknown whether these are conspecific populations or cryptic species. Most of the potential examples remain taxonomically weak, are in need of revision by a close comparison between the Neotropical and the SE Asian populations, and mostly the latter remain to be investigated (e.g. the SE Asian Ephemeroporus, Streblocerus cf. pygmaeus and Oxyurella cf. longicaudis). Interestingly, in its habitat in Thailand (swamps), we found Leydigiopsis in association with a number of species that form a similar community in South America. In the Lençoís Maranhenses in Brazil (Van Damme and Dumont, 2010), species associated with Leydigiopsis in dystrophic temporary habitats are Streblocerus pygmaeus Sars, 1901, Macrothrix sioli Smirnov, 1982, Alona ossiani Sinev, 1998, Anthalona verrucosa (Sars, 1901), Cyclestheria hislopi (Baird, 1859), etc. (Van Damme and Du- 
mont, 2010). In Thailand, Leydigiopsis is found in association with the vicariants of the latter (Streblocerus $\mathrm{cf}$. pygmaeus, Macrothrix pholpunthini Kotov, Maiphae et Sanoamuang, 2005, Alona cf. affinis (Leydig, 1860), Anthalona harti Van Damme, Sinev et Dumont, 2011, C. hislopi, etc.) (Van Damme et al., 2013b). Hence, it is not just a disjunct species, but a vicariant community. It should be no surprise that under similar climatic conditions and similar habitats, a similar set of cladoceran species can be found on each continent, an argument for vicariance and ancient origin of the group (e.g. Frey, 1986). However, it is remarkable that three South American-SE Asian disjunct pairs (in Leydigiopsis, Macrothrix Baird, 1843 and Streblocerus Sars, 1862), with a type of distribution which is rare in the Cladocera, can actually be found in association on either side of the Pacific. Rather than a random effect, we think that this is a case of relictualism and of range contractions of a formerly widely distributed habitat and its taxa, and a subsequent speciation as a result of fragmentation.

The low chances of long distance dispersability of benthic chydorid ephippia, intolerance for brackish or saline water in Leydigiopsis and the low tolerance of cold temperatures of this lineage, and the fact that this is a distinctively different species with local phenotypic variation, make it highly unlikely that a recent long-distance dispersal scenario can explain the current disjunction. Ephippia of Leydigiopsis do not float (KVD, personal observation), they are deposited in the detritus layer where animals live. High dispersal and colonisation abilities have been attributed to Cladocera, but only for small spatial scales (few $\mathrm{km}$ ), not over extreme distances. Besides the dispersability, there is also competition to consider (De Meester et al., 2002), where resident populations have the advantage. It is unlikely that benthic ephippia from South America dispersed recently by wind, birds or sea over a distance as wide as the Pacific. Dispersal over the Pacific by wind is possible for bacteria and Archaea (Smith et al., 2013), but it is highly unlikely for ephippia. In the scenario where we assume recent disperal and colonisation over such a distance, we would expect the species all over the Pacific islands, across the Wallace line, in Australia and New Zealand. However, the genus is not present on the Pacific islands, which are poor in Cladocera (Schabetsberger et al., 2009) and it does not occur in Australia or New Zealand (e.g. Smirnov, 1995). In the scenario where we assume easy dispersal and colonisation, we would expect the group to be present in the areas in between (Australia, New Zealand, Pacific islands), which is not the case. Leydigiopsis species are confined to freshwater, live in muddy conditions in shallow temporary freshwater pools and swamps, with optimal temperatures not below $25^{\circ} \mathrm{C}$ (optimal in culture from $28^{\circ} \mathrm{C}$ up, no hatching of the eggs below $25^{\circ} \mathrm{C}$ ), in nature very abundant at $31-33^{\circ} \mathrm{C}$ (Van Damme and Dumont, 2010). The fact that Leydigiopsis is rather specialised, makes it useful for biogeography: i) stenothermic, intolerant to cold, therefore confined to tropics so no chance of dispersal through higher latitudes via recent New World-Old World connections (e.g. Bering Strait) during cold periods (Quaternary); ii) freshwater, can tolerate low conductivities, low oxygen conditions, but not brackish or saline water, so no chances of long-distance dispersal with ocean currents, only by over-land dispersal. Especially tolerant for low $\mathrm{pH}$ (Van Damme and Dumont, 2010), therefore able to live in acid waters; iii) benthic specialist, with typical adaptations and colored red from hemoglobin, lives in muddy conditions and detritus in humic-rich, dystrophic swamps and in shallow pools, needs a layer of organic plant matter to live in and able to withstand low oxygen conditions; iv) dispersal by ephippia, which are not aimed at long distance dispersal in benthic chydorids, but mainly at building in situ eggbanks (in fact, embryobanks). Ephippia sink and are deposited together with the vegetation and mud. The ephippia can withstand complete drying and even strong heat, like in short lived, ephemeral pools in semi-desert conditions like in the dune pools of the Lençoís Maranhenses, Northeast Brazil (Van Damme and Dumont, 2010).

A direct biogeographical connection between South America and SE Asia is currently hard to imagine. It is most likely that the stenothermic tropical genus Leydigiopsis had a wider distribution in the past and subsequently disappeared from regions where temperatures became limiting and suitable habitats fragmented. So relictualism, rather than recent dispersal or a human introduction, is favoured here. The idea corresponds also to the fact that Leydigiopsis limbs has a rather primitive phenotype in the Aloninae (Sinev, 2004a, 2004b), with relatively conserved limb morphologies, so we can expect a rather ancient distribution pattern, considering a PalaeozoicMesozoic age of most Chydoridae genera. Under a relictualism/extinction scenario, there are still several possibilities, but we can assume that the observed pattern is not a recent one. An overview of the scenarios that could explain the current disjunction and the pros and cons of each hypothesis, is given in Tab. 1.

\section{Plants may provide useful parallels for exploring anomopod biogeography}

As the fossil record is poor for Anomopoda (e.g. Kotov, 2009) and molecular studies are lacking for almost all tropical cladoceran taxa, it is currently impossible to retrace their biogeographical history in detail - a comparison with other groups is necessary. As noted in the Introduction, there is not so much known of this type of disjunction in other zooplankton groups and on other epigean freshwater crustaceans to compare with. Further- 


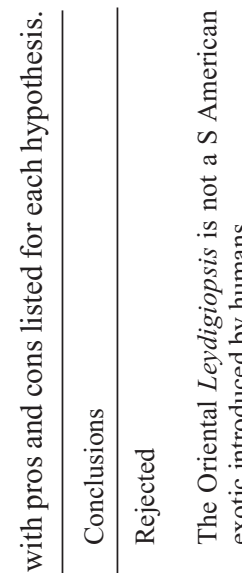

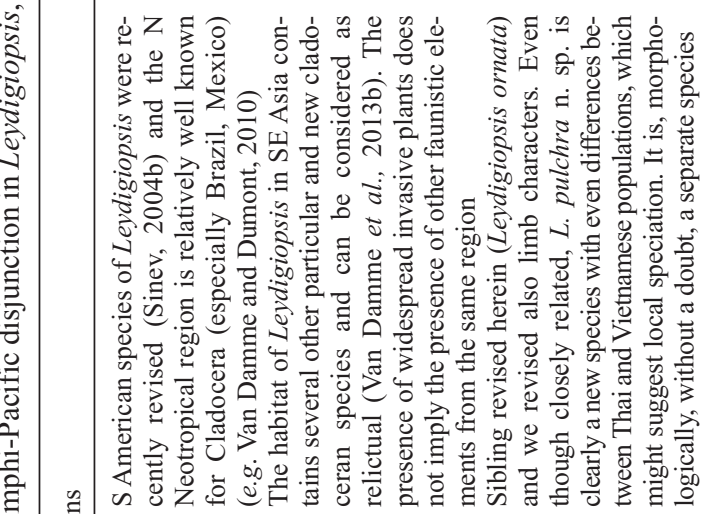
¿

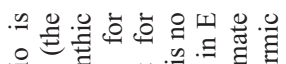

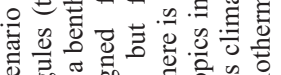

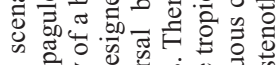

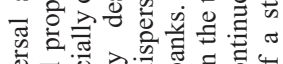

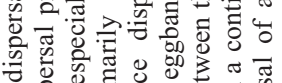

के क्ष

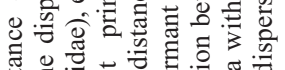

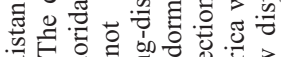

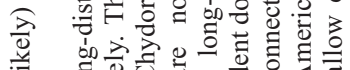

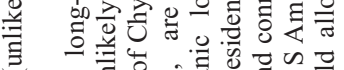

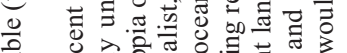

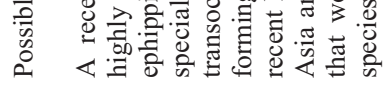

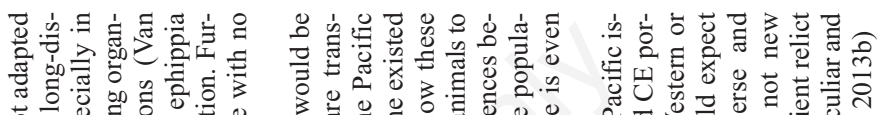

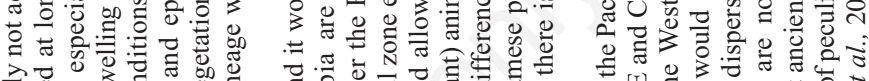

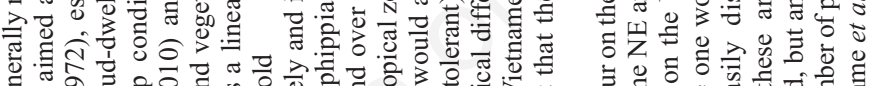

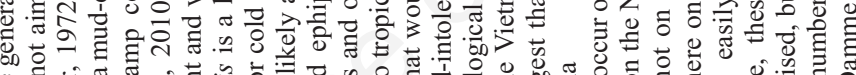

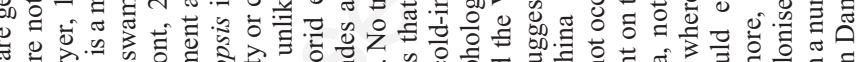

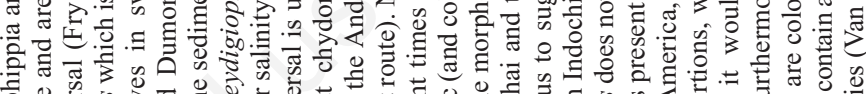

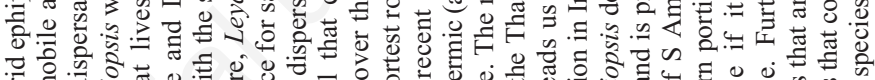

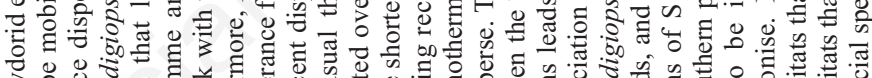

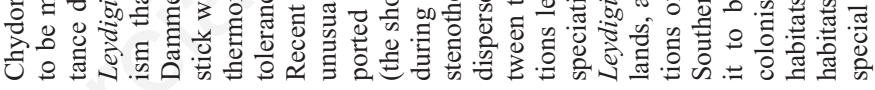
$-\dot{0}$

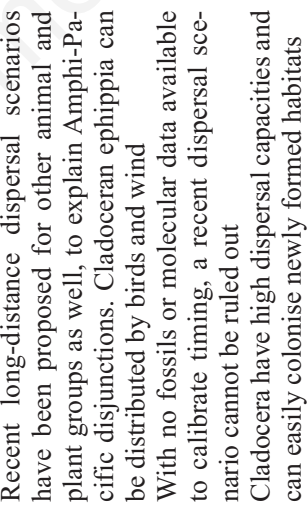

$-\dot{ }$

$\stackrel{3}{\circ}$

要

节产

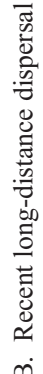

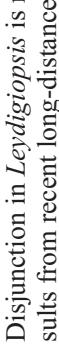




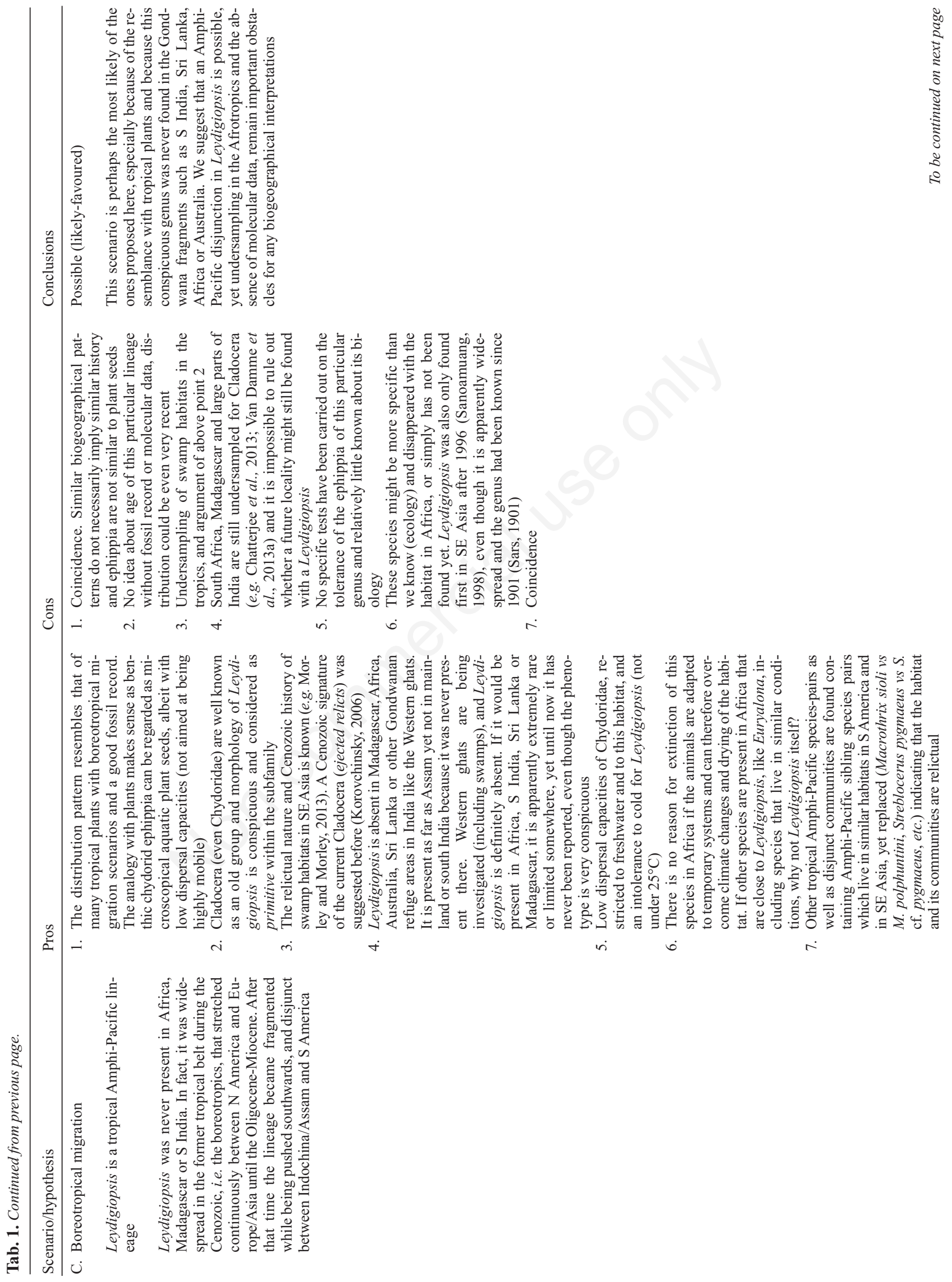




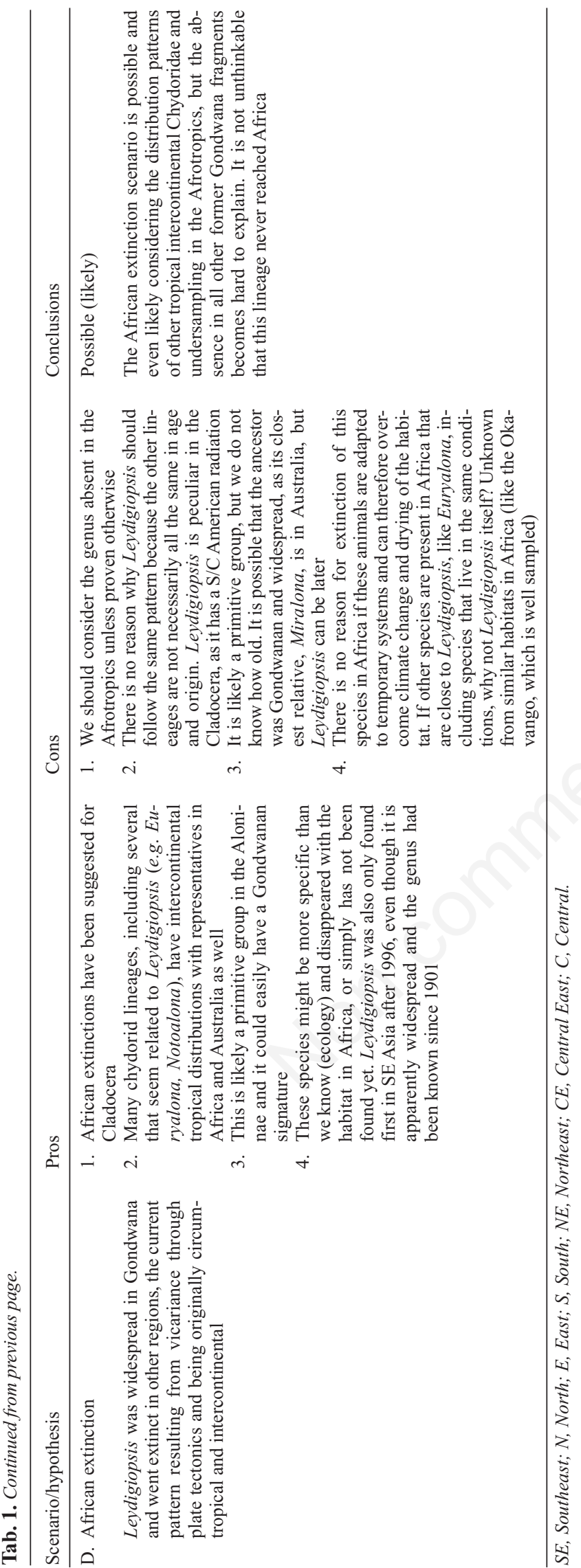

more, it might be incorrect to compare biogeographical patterns of Anomopoda with other animal groups without comparing the modes of dispersal first. Resting eggs enclosed in ephippia (Fig. 10), which may survive periods of drought and can be distributed by wind, are the major propagules for dispersal in the Anomopoda and may form extensive seed banks in temporary pools (Vandekerckhove et al., 2005a, 2005b). In fact, anomopod resting eggs behave like minute aquatic seeds for dispersal: functionally, ephippia are very similar to plant seeds, and the same dispersal mechanisms may operate (Altermatt and Ebert, 2008; Figuerola and Green, 2002). Parallels between dormant eggs encased in special structures in the branchiopods and plant seeds have been suggested since long in relation to the adaptations to unstable conditions, dispersal strategies, egg banks, life histories and mechanisms for germination/hatching (Korpelainen, 1986; Figuerola and Green, 2002; Brock et al., 2003; Ripley et al., 2004; Vandekerckhove et al., 2005a, 2005b; Altermatt and Ebert, 2008). Makrushin and Lianguzova (2006) studied plant and cladoceran resting stages together and compared them as dormant functional units in experiments on chemical permeability of the outer casings. However, parallels between plant seeds and anomopod ephippia have rarely been taken into account for the interpretation of anomopod biogeography. More is known on dispersal mechanisms in daphniids than in chydorids, yet we know that in the latter group, the ephippia are glued to plant remains and the relation between the resting stage (Fig. 10) and the (plant) substrate is intimate (Fryer, 1972). We think that parallels with plant biogeography could make more sense than comparing anomopod distributions with animal groups that have no such seed-like resting stages. Diapause exists in many aquatic crustaceans (in fact, in many aquatic invertebrates) (Alekseev and Starobogatov, 1996; Alekseev et al., 2007), yet the drought-resistant, pod-like ephippia in the anomopod branchiopods are quite special. Therefore, from a biogeographical perspective, anomopods can be approached as seed plants, perhaps even more so than as animals.

In the case of Amphi-Pacific disjunctions, the parallel is very useful: much has been written about the megathermal angiosperms, the tropical flowering plants and the fossil record is well known (Morley, 2000). For a large number of tropical plant families, the main hypothesis proposed to explain disjunctions between the Neotropics and SE Asia, if not by transoceanic long-distance dispersal or vicariance, is the boreotropical scenario (Wolfe, 1975; Morley, 2000, 2001; Tiffney and Manchester, 2001). The number of tropical plant genera with an Amphi- and transPacific disjunction is impressive (van Steenis, 1962) and the boreotropics hypothesis has been confirmed by molecular analysis for a number of families, like the Lauraceae, Annonaceae, Malpighiaceae and the Fabaceae 
(Lavin and Luckow, 1993; Chanderbali et al., 2001; Davis et al., 2002, 2005; Lavin et al., 2005; Li et al., 2011; Christenhusz and Chase, 2013). The discussion is pivotal to our current understanding of biogeography in general (McCarthy et al., 2007) and to explain the origins of plants in the Old and New World tropics (Morley, 2000). According to the boreotropical migration hypothesis (Wolfe, 1975; Tiffney, 1985; Lavin and Luckow, 1993; Morley, 2000, 2001; Tiffney and Manchester, 2001; Christenhusz and Chase, 2013), which is based on an extensive fossil record, many of the extant tropical plant taxa with an Amphi-Pacific disjunction originated from a centre of radiation in the Northern Hemisphere and formed the boreotropics, a continuous biome stretching out during the Eocene between more northern latitudes in the Old and New World (Europe and North America) and with relatives in Central America and tropical Asia. The biome underwent fragmentation and taxa went extinct at higher latitudes, currently finding refuge at lower latitudes, after temperatures declined after the early Oligocene. It is a widely assumed hypothesis for plant groups that show a link between SE Asia and the Neotropics, but not with Africa (Christenhusz and Chase, 2013). For Cladocera, the timing would make sense, as the Cenozoic is thought to have left a lasting mark on current distributions through extinctions, leaving a group of relicts behind (Korovchinsky, 2006). Scenarios of vicariance through plate tectonics and the break-up of Gondwana are equally common for Neotropical plants with Amphi-Pacific disjunctions (Christenhusz and Chase, 2013).

\section{African extinction or boreotropics?}

From a relictualism scenario, there are two major possibilities for Leydigiopsis. The genus can have a vicariant Gondwanan distribution, formerly present over complete southern Gondwana, or it was in fact never present on other Gondwana fragments. We labeled the first as the Africa extinction scenario and the second, the Boreotropical migration scenario (Tab. 1). The boreotropics scenario has not been taken into account before for this kind of disjunctions in freshwater invertebrates and we would like to mention it here at least as a possible biogeographical hypothesis that hitherto seems to be mainly part of botanical research and worth exploring for animals.

According to the Africa extinction scenario, the origin of Leydigiopsis would pre-date Gondwana break-up. Leydigiopsis would have been well established in warmer regions of Gondwana, where suitable climatic conditions were present before the break-up of this continent in the early Jurassic. Through connections with Laurasia (which

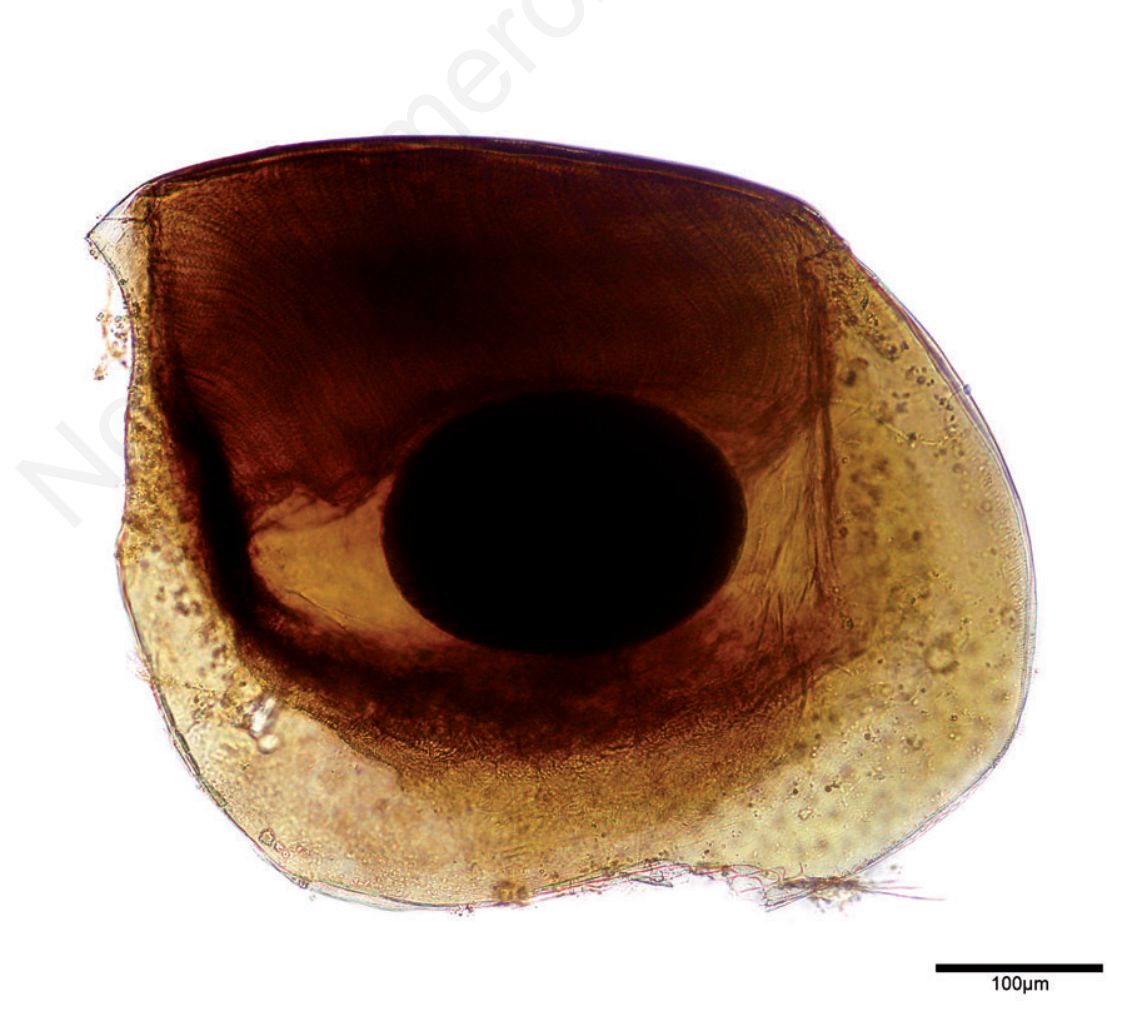

Fig. 10. Ephippium of Leydigiopsis pulchra n. sp. from a small forest lake near Bau Sau lake, Cat Tien National park, Dong Nai province, Vietnam, coll. May 2009, by A.Y. Sinev. Ephippia of the benthic Chydoridae are deposited with the substrate, they are not primarily aimed at long-distance dispersal. The resting egg (in fact, dormant embryo) can be interpreted as microscopic dormant seeds, encased by a drought-resistant shell. Functional similarities between anomopod resting eggs and plant seeds can be useful for the interpretation of anomopod biogeography. 
was in fact a group of smaller continents, not a single united landmass), Leydigiopsis entered Asia during warmer periods, but gradually disappeared in colder regions and became extinct through a decline in suitable habitat from tropical lowlands. Such a habitat decline is not unlikely. For example, though climatic conditions are favourable for the occurence of Leydigiopsis in Africa, dystrophic swamps are currently relatively rare in the tropical African lowlands, and more common at higher latitudes (Van Damme and Eggermont, 2011).

When considering the Boreotropical migration scenario, we can notice how Leydigiopsis may have originated at higher latitudes in Laurasia (for example in North or Central America), after the break-up of Gondwana, and was present in Asia during the warm global climate in the Eocene, at which time it had a wide distribution together with the tropical habitat, swamps in wet tropical forests of the boreotropics biome. Species gradually went extinct at higher latitudes in the Americas and/or Eurasia in regions where cooling occurred and the biome was pushed southward, and survived in relic habitats in SE Asia and Central and South America. In the latter scenario, Leydigiopsis species went extinct at all higher latitudes in Eurasia and North America, have never reached Africa or Madagascar, nor crossed the Wallace line to Australia, and have never been part of the Indian Ark fauna.

Leydigiopsis is absent from major Gondwana fragments, such as Australia. On the latter continent, an endemic close relative occurs, which seems morphologically closest to a direct ancestor (Miralona victoriensis; Fig. 9). We think that an ancient origin of the ancestral line is not unlikely, but Leydigiopsis could be a younger branch. It is generally assumed that anomopod families and even chydorid genera were well diversified by the Mesozoic (Sacherová and Hebert, 2003; Kotov, 2009). In the absence of fossils, analysing patterns of distribution, combined with our ideas on primitive and advanced morphologies in Aloninae may help us to provide important clues about timings of main radiations. In Leydigiopsis and Miralona, both morphology and distribution suggest an ancient clade. However, lacking good fossil records, time estimates on the origin of chydorid genera are based on assumptions and we are at a guess when or where they originated. In contrast to Daphnia, whose timings of origin are well-studied (Kotov and Taylor, 2011), chydorid diversity has only been probed at deeper levels once, a decade ago (Sacherová and Hebert, 2003).

From morphology, we assume that the related $E u$ ryalona, Tretocephala, Miralona and Leydigiopsis are likely relicts of an ancient radiation. Tretocephala is a cold-tolerant genus that shows a morphological link with Leydigiopsis (Sinev, 2004a, 2004b), with a South AfricanPalaearctic disjunction and Euryalona is a circumtropical genus with intercontinental divergence. However, while the ancestral line could be even Pangaean in origin (Miralona-Tretocephala-Euryalona), Leydigiopsis itself is not necessarily as old, or perhaps it originated somewhere else, like in Laurasia, with a radiation in Central Americas or the Amazon basin, where its centre of diversity currently lies.

The Africa extinction scenario and a Gondwana-origin seems perhaps the first that comes to mind to explain the presence of Leydigiopsis in SE Asia (Maiphae et al., 2008), and it would mean that the genus could still be expected in Africa in the future, after more intense surveys on the huge continent. In fact, a Gondwana vicariant pattern is the general and mostly favoured assumption to explain disjunctions of this type in other groups as well, but not necessarily the correct or the only one (Christenhusz and Chase, 2013). Africa likely underwent severe extinctions in the Cladocera and the continent is among the poorest studied regions in the cladocerans, yet with high potential for endemic zones such as Southern Africa (Van Damme et al., 2013a), where we might expect another vicariant. There is a link between several of the South African endemics (which are poorly known) and Australia, but not with SE Asia (Van Damme et al., 2013a). However, Leydigiopsis has never been found in any of the other major Gondwana fragments in the tropics, such as Africa, India, Sri Lanka, Madagascar or Australia. For a modern distribution to appear Gondwanan, it should involve more than one ocean basin (Nelson and Ladiges, 2001). Even though India, Sri Lanka (Chatterjee et al., 2013), large portions of Africa (Van Damme et al., 2013a, 2013b) and Madagascar are not well known, Australia is better investigated for Cladocera. We can rule out Leydigiopsis from the Western ghats in India, where a wide range of habitats is recently investigated (S. Padhye, unpublished data) and the taxon does not occur in rich samples collected from Madagascar (H.J. Dumont, unpublished data), or south of Chatterjee's partition in India (Chatterjee and Scotese, 1999), where typically Gondwanan elements are expected. The habitat would not be the major bottleneck in warm regions, because the fact that the ephippia can withstand periods of drought, would allow these species to colonise similar conditions in Africa, even though extensive swamp areas are not as common in the lowlands of the Afrotropics (and much more extensive in SE Asia). Until now, there is definitely no Leydigiopsis in similar habitats in Africa, such as the Okavango (Republic of South Africa/Botswana), while other circumtropical genera are present there (Notoalona, Euryalona, Anthalona, etc.). There is no reason why increased aridity on the African continent would have caused the extinction of Leydigiopsis, as these animals reside very well in highly temporary systems, such as the dune pools in NE Brazil (Van Damme and Dumont, 2010). So the extinction in Africa, and in fact, the extinction in all other Gondwana fragments such as Australia or mainland India, becomes hard to understand. If 
Leydigiopsis had taken the southern transantarctic dispersal route in a Gondwanan scenario (Sanmartín and Ronquist, 2004), then it would have been expected south of the Wallace line or in more southern portions of South America, which is not the case. The penetration of Leydigiopsis into South America seems to come from the north (from Central America to middle of South America), not from the south.

The boreotropics hypothesis is perhaps more plausible than the African extinction scenario, because it does not require searching for an explanation as to why Leydigiopsis is absent in other Gondwana fragments, besides the possibility of undersampling. As for tropical plants, many faunal elements might not have reached Africa, a continent which lacks the everwet rain forest components of wet rain forest floor, herbs/orchids/palms/understory trees etc., while the semi-deciduous flora has about the same diversity as in other tropical areas (Morley, 2000). It also corresponds to the ejected relicts hypothesis and the Cenozoic signature on the extant Cladocera (Korovchinsky, 2006). The distribution pattern in Leydigiopsis is different from most tropical Amphi-Pacific or trans-Pacific disjunctions, because it does not involve New Zealand or Australia or the western or southern portions of South America. Instead, it includes Indochina, Assam on the Oriental side and Mexico+Central America and the Northto Central East portions of South America on the Neotropical side (Fig. 9). This is exactly the distribution expected for the boreotropics hypothesis and that is well-studied in plants, as the genus could have expanded southwards from the north to the southeast and central east portions of South America. Leydigiopsis would never have been in Africa in the first place, and it could be Laurasian, not Gondwanan, in origin. Recently, Kotov and Taylor (2011) suggested an important Laurasian Cenozoic signature for Daphnia/Ctenodaphnia as well and it is possible that Laurasia (even though this was never a truly united landmass) was an important region for evolution of the Anomopoda. In India, Leydigiopsis occurs in Assam but not further south, therefore it is not present in any of the Gondwanan refuge areas, so there is no evidence to suggest that it was part of the Indian Ark fauna and thus would have previously occurred in Africa - if this taxon had occurrences in the Western Ghats or Sri Lanka, African extinction would be the obvious explanation, but that is not the case (R. Morley, personal communication). It is not unthinkable that populations of Leydigiopsis were fragmented with the habitat itself and thus a comparison with the biomes to which the habitat belongs and the associated tropical flora (which is much better studied), is not far-fetched. The possibility of chydorid taxa being widely distributed in an everwet tropical forest floor, in swamps and wetlands stretching out across Eurasia and North America during the Eocene in a continuous warm climatic belt, with relatives in Central America and the
Asian tropics, until cooling pushed the taxa further southwards and caused extinction in North America and the Palaearctic, should at least be considered. As Christenhusz and Chase (2013) noted on boreotropical plants: thus, relationships of these lineages in South America are not directly linked to African taxa...; they also date from much more recent times (30-40Mya rather than $>65 \mathrm{Mya}$ ). Townsend et al. (2011) suggested the same age for the SE Asian-Mexican disjunction in dibamid lizards using molecular methods and noted the importance of the boreotropical forest belt for the dispersal of their group. We suggest that the biome has played a crucial role in aquatic invertebrate dispersal during the Eocene as well. In fact, the early Cenozoic was a period of intense faunal and floral exchange for all groups: it was the most important time for high-latitude exchange of thermophilic taxa between the Eurasian and American faunas through the Beringian land bridge on the Pacific side (55-35Mya ago) and the Thulean bridge ( $c a .55-50 \mathrm{Mya}$ ) and De Geer route on the Atlantic side (McKenna, 1983; Tiffney, 1985; Keogh, 1998; Rose, 2006; Archibald et al., 2011; Townsend et al., 2011; Guo et al., 2012). The boreotropics hypothesis for plants (e.g. Tiffney, 1985) can be used, like the theory of ousted relicts for terrestrial arthropods (e.g. Eskov and Golovatch, 1986), to explain tropical trans- and Amphi-Pacific disjunctions by a southern migration of previously more northern taxa due to climate cooling in the Cenozoic. The ejected relicts hypothesis on Cladocera (Korovchinsky, 2006) does not contradict the former, although it does not specify on trans-Pacific or Amphi-Pacific disjunctions.

As the boreotropics consisted of evergreen wet tropical forests, it is likely that there was a large habitat continuity, under the same tropical climatic conditions of detritus-rich freshwater habitats in the form of swamps and temporary shallow forest pools with a lot of leaf litter and humic substances. We found Leydigiopsis in swamps in Thailand habitats which have a highly relictual character (Morley, 2013; Morley and Morley, 2013) often from deforested regions harbouring significant endemism and diversity. The habitat clearly plays an important role in cladoceran evolution (Van Damme et al., 2013b). In Vietnam, we found Leydigiopsis in a forest pool, rich in leaf litter, which is no doubt a habitat as old as tropical forests themselves that has been continuous through time.

Therefore, not only the biome (boreotropics) might have been important for the dispersal and evolution of megathermal floras and terrestrial animals, but for the distribution and the evolution of stenothermic, tropical freshwater zooplankton as well. However, if the boreotropics played such a crucial role, it remains unclear why no more cladoceran lineages than the ones suggested here, have an Amphi-Pacific disjunction. Closer taxonomical revisions and molecular analysis on circumtropical cladoceran line- 
ages, should shed a clearer light on this issue in the future.

At present, our knowledge of the African faunas is too limited (Van Damme et al., 2013a) to completely rule out the presence of Leydigiopsis on the latter continent (a similar case might be true for India; Chatterjee et al., 2013). However, this study highlights the need for more biogeographical research in the cladocerans and the need to be open to different hypotheses that could be tested by using molecular methods. We hope that this work can increase the attention to tropical Amphi- and trans-Pacific disjunctions in freshwater invertebrates and spur researchers in zooplankton biogeography to explore more hypotheses besides a Gondwana vicariance scenario. As Eskov and Golovatch (1986) suggested for millipeds: any attempts at deriving the recent patterns directly from ancient continental drift like Gondwanaland fragmentation must be cautioned. Also for chydorid lineages with intercontinental distributions, falling under Frey's $(1986,1987)$ vicariance scenario, we should be open to other hypotheses. For Cladocera biogeography, we think that the importance of evolution in Laurasia and in particular, the importance of boreotropics, deserve closer attention.

\section{Undersampling of shallow pools and swamps in the tropics}

The scarcity of this species in the Oriental region could partly be linked with a human-mediated destruction of its habitat. Swamps in SE Asia are under major threat of infrastructure works and many have disappeared before their cladocerans were studied (e.g. in Thailand; Van Damme et al., 2013b). A similar case was recently mentioned for the endemic Cladocera in South Africa, where temporary pools, considered important for microcrustacean evolution, are understudied ephemeral habitats vulnerable to destruction (Van Damme et al., 2013a). Though Leydigiopsis will undoubtedly still be found in more localities in SE Asia, it actually faces local risk of extinction through a decline of its habitat, which harbours other rare endemics. The typical habitat for Leydigiopsis may be an example of how ancient chydorid habitats looked like in the tropics, which covered a larger area, temporary swamp-like habitats playing an important role in cladoceran evolution and divergence. With the disappearance of such habitats and their specialised disjunct faunas, the science of biogeography itself is under threat (Schram, 2008), therefore a continuation of survey efforts and taxonomy are important, not only from a biodiversity perspective.

Even though in all of the above we have been mainly following the assumption that this is a natural disjunction, it is impossible to exclude that undersampling of the particular habitat in which Leydigiopsis resides, and of complete regions (e.g. in Africa), could be behind the current observed pattern. All kinds of disjunctions exist in the Cladocera, and certainly not all can be explained by natural processes, yet result from our lack of knowledge. Besides undersampling and our poor knowledge of the Cladocera in the Afrotropics, temporary pools and swamps are strongly underestimated habitats in zooplankton surveys anywhere, yet this is where the true diversity of the Cladocera resides (Van Damme et al., 2013a, 2013b). Taxonomical resolution is definitely an obstacle in the majority of the Cladocera examples that we listed, where revisions are still needed. This is a general phenomenon for SE Asia (Korovchinsky, 2013) and in fact, for other regions as well (Forró et al., 2008). In the absence of unambiguous pre-Pleistocene chydorid fossils, molecular methods could be most helpful in understanding historical biogeography by allowing an age estimation of species divergences. For purely stenothermic/tropical cladoceran genera like Leydigiopsis, no molecular phylogenetic work, comparing species from different continents, has been carried out so far. In general, extensive molecular phylogenies have mostly focused on the planktonic groups, in particularly on the Daphniidae (Adamowicz et al., 2009), and publications on molecular data of the Chydoridae are poor (Sacherová and Hebert, 2003; Van Damme et al., 2007). A sequence of the $18 \mathrm{~S}$ nuclear ribosomal gene is available for L. curvirostris from Brazil (Van Damme et. al., 2007), but it lacks a comparison with other Leydigiopsis species or related genera. Also, intergenic spacers ITS1-2 have been sequenced as part of the latter study, and these nuclear ribosomal markers can be used, in combination with other markers, to have a rough idea on an age of divergence in chydorid lineages, as demonstrated for the Chydorus sphaericus-complex. The nuclear ribosomal sequence of $L$. curvirostris can be a useful start, but more markers should be investigated [e.g. 16S, c oxidase subunit I (COI), etc.], preferably of all species in the genus and in comparison with other genera (e.g. Euryalona, Tretocephala, Miralona, etc.). This would allow us - at least roughly - to assess whether the observed pattern of divergence in Leydigiopsis could be indeed mainly Cenozoic, as the boreotropical migration scenario would imply, and whether the split of the Oriental species comes before or after divergence of the Neotropical species. There is an urgent need for molecular screening of the non-planktonic cladoceran taxa from tropical Asia, which should be performed by regional institutes to allow a firm understanding of biogeography, diversity and evolution in the group. DNA barcoding of several Neotropical taxa has been undertaken in Mexico (e.g. Elías-Gutiérrez et al., 2008), which is based on firm taxonomy, but a wider taxon sampling and a screening at higher levels (genera), remains a task for the future. Also, a better understanding of the fossil record is very important, and in fact it seems possible with a focused effort (Kotov, 2007).

Unfortunately, undersampling, the need for taxonomical revisions and the scarcity of molecular and fossil data, currently remain major obstacles for the interpretation of any biogeographical pattern in the non-planktonic tropical 
freshwater cladocerans. In fact, the same is true for most of the other zooplankton groups (rotifers, copepods) or even freshwater invertebrates in general. We have shown here that trans- and Amphi-Pacific disjunctions may occur in zooplankton as well and that the pattern has not been well-studied. A focus on the tropical disjunctions in aquatic invertebrates, such as the speciose non-planktonic Cladocera, will help us to understand more about biogeographical patterns and evolution of the group as a whole.

\section{CONCLUSIONS}

The SE Asian/Oriental Leydigiopsis is a morphologically separate species, easily distinguished from all Neotropical taxa. We suggest that the genus has a relictual distribution, i.e. the current disjunction is not a recent dispersal event or a human introduction from the Neotropics. Representatives of this stenotherm lineage and the corresponding habitat were more widespread in the past and disappeared from connecting regions, leaving a relict species in SE Asia. We propose that the Amphi-Pacific disjunction of Leydigiopsis species may well parallel tropical flowering plant taxa with similar relictual distributions. The disjunction resembles a boreotropical migration scenario, in analogy with plants, although we cannot rule out an African extinction scenario or even an artefact due to the limited knowledge of the Afrotropical cladocerans. While we cannot know where the genus originated, the current centre of diversity of Leydigiopsis lies in Central and South America. The habitat, i.e. tropical swamps, is important for our understanding of anomopod biogeography and diversity, while at the risk of disappearing.

To think about biogeography in the Anomopoda may significantly benefit from a comparison with well-studied plant groups showing similar patterns of distribution when keeping in mind that the ephippia, the anomopod propagules for dispersal, can be regarded - from a biogeographical point of view - as microscopic seeds. We have attempted to explore some parallels here and we think that much more can be learned in Anomopoda from a closer examination of their dispersal mechanisms, in comparison with the biogeographical scenarios in plants, where the diversity, the fossil record and molecular data are considerably richer.

\section{ACKNOWLEDGMENTS}

We are grateful to Dr. R. Morley, Dr. T. Karanovic, Dr. J. Reid, Dr. C. Rogers, Dr. H. Segers, Dr. A.A. Kotov, Dr. N.M. Korovchinsky, Dr. J.C. Briggs and Dr. D. McCarthy for suggesting valuable literature and providing important comments on this manuscript. In particular, the comments by R. Morley on this type of disjunctions in tropical plants and important references were thankfully received. Thanks to Dr. L. Sanoamuang and Dr. M.K. Hołyńska for inviting the authors to the FISA Workshop at Maha Sarakham, Thai- land. This paper is part of the 2012 FISA Workshop Proceedings. KVD would like to thank Dr. S. Maiphae, P. Saardrit and Dr. P. Pholpunthin (Prince of Songkla University) for the joint sampling and their continuous support in Cladocera research in Southern Thailand. Collection of material in Vietnam of AYS was supported by and performed at the Joint Russian-Vietnamese Tropical Research and Test Center, South Division, Ho Chi Minh City, Vietnam. Special thanks to Anna B. Vasilieva and Nikolai A. Poyarkov for help during the sampling in Vietnam, and to Alexey A. Kotov for the $L$. ornata specimens from Tabasco State, Mexico. The research of AYS was partly supported by the Russian Foundation for Basic Research (grant 13-0401065-a) and by the Ministry of Education and Science of the Russian Federation (14.740.11.1049, 8334).

\section{COMMENTS}

Although unusual, we include a few remarks here by the reviewers, as valuable points in the discussion. Dr. Korovchinsky remarked that: The authors support a relictualistic direction in zoogeography and this is the right position. At the same time, they mostly discuss the boreotropical hypotheses and Africa extinction hypotheses, favouring the former one. In other words, they connect the origin of Leydigiopsis in any case with only one of the ancient landmasses. However we know too little to do this and to propose the absence of the group in Africa and other regions seems not realistic. In pre-Oligocene times, when climate in general did not have the sharp gradations with appeared later and formed the recent welldelineated tropical and boreal zones, most probable the organisms, including Leydigiopsis, had global or at least very wide distribution. Then, along with climatic and geological perturbations, the mass extinctions and biome's reconstructions followed and different groups that not went extinct, survived here and there as relicts. Leydigiopsis probably did the same, but it is unknown where its recent range comes from. From Pangea? Probably (possibly)... In particular, the western tropical part of Africa, where some cladoceran endemics are known, is really poorly sampled and investigated, at least worse than Thailand. We agree with Dr. Korovchinsky that the lack of knowledge of the African faunas (Van Damme et al., 2013a) and in particular of Western Africa, is a major problem in interpretation of such disjunctions in the Cladocera. The fact that a similar pattern has been well investigated in plants and other groups, prompted us to propose the boreotropics hypothesis as a potential and useful alternative, worth considering when investigating cladoceran biogeography. We do not (and cannot) rule out the former possibility (former presence in Africa and other Gondwana fragments), yet we find it useful here to explore more than Gondwanan scenarios alone and explore parallels with other groups (e.g. plants) where the fossil 
record is very rich. Furthermore, a Laurasian origin rather than a Pangean origin could also be an alternative to consider. Another remark was given by Dr. Morley: The argument against an African route or a trans-Pacific route, could be made a lot stronger by linking climate continuity, habitat continuity and tectonics - more can be made of the absence in Madagascar, Sri Lanka and the Ghats, and the absence of records in India southward of Chatterjees Partition. If a boreotropical group, it would have become relict along the southern coast of the $N$ American plate in the Miocene, then dispersed south with the formation of the Panama isthmus, then contracted its range following Pleistocene Glaciation. The latter remark is very useful in considering the boreotropics as a valid alternative hypothesis to the African extinction scenario.

Key to the adult parthenogenetic females of Leydigiopsis Sars, 1901

Our revised key of the Leydigiopsis species of the world (Fig. 11) builds on Smirnov (1971), updated with

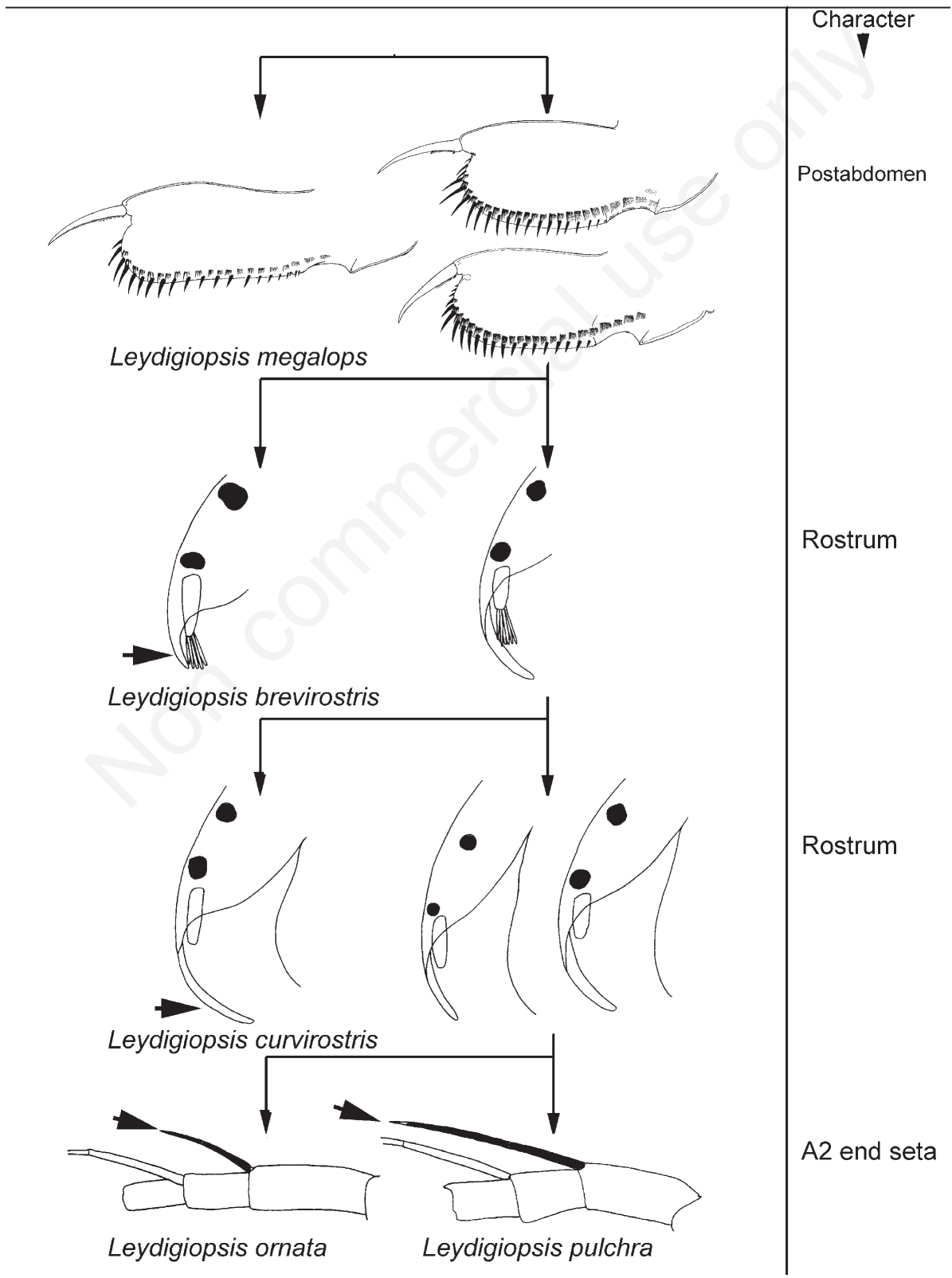

Fig. 11. Pictorial key to the adult parthenogenetic females of the genus Leydgiopsis Sars, 1901. The key is based on Smirnov (1971), updated with the recent revisions and it includes the new species. 
observations and redescriptions from Valdivia Villar (1984), Sinev (2004b), Van Damme and Dumont (2010) and this study.

1. Postabdomen broad, with maximum height near the middle of the postanal margin

Postabdomen narrow, widening distally, with maximum height close to the end of postabdomen

.......Leydigiopsis megalops Sars, 1901 (Neotropics)

2. Rostrum reaching beyond the antennular aesthetascs.

Rostrum not reaching beyond the antennular aesthetascs .........Leydigiopsis brevirostris Brehm, 1838

..(Brazil)

3. Rostrum weakly curved

...4

Rostrum strongly curved inwards............Leydigiopsis curvirostris Sars, 1901 (Neotropics)

4. Seta on the first segment of the antennal endopod short, just reaching over the second endopod segment. Apex of labral keel acute ............Leydigiopsis ornata .Daday, 1905 (Neotropics)

Seta on the first segment of the antennal endopod long, reaching the end of the third endopod segment or beyond. Apex of labral keel blunt .......Leydigiopsis pulchra n. sp. (Indochina, Assam)

\section{REFERENCES}

Adamowicz S, Petrusek A, Colbourne, JK, Hebert PD, Witt JD, 2009. The scale of divergence: a phylogenetic appraisal of intercontinental allopatric speciation in a passively dispersed freshwater zooplankton genus. Mol. Phylogenet. Evol. 50:423-436.

Alekseev VR, De Stasio B, Gilbert JJ, 2007. Diapause in aquatic invertebrates, p. 10-20. In: H.J. Dumont (ed.), Monographiae biologicae. Springer.

Alekseev VR, Starobogatov YI, 1996. Types of diapause in Crustacea: definitions, distribution, evolution. Hydrobiologia 320:15-26.

Allen RA, 2007. Measuring and modeling dispersal of adult zooplankton. Oecologia 153:135-143.

Altermatt F, Ebert D, 2008. The influence of pool volume and summer desiccation on the production of the resting and dispersal stage in a Daphnia metapopulation. Oecologia 157:441-452.

Archibald SB, Johnson KR, Mathewes RW, Greenwood DR, 2011. Intercontinental dispersal of giant thermophilic ants across the Arctic during early Eocene hyperthermals. P. R. Soc. B. 278:3679-3686.

Ashley MV, Norman JE, Stross L, 1996. Phylogenetic analysis of the perissodactylan family Tapiridae using mitochondrial cytochrome $c$ oxidase (COII) sequences. J. Mamm. Evol. 3:315-326.

Bakar BH, 2004. Invasive weed species in Malaysian agroecosystems: species, impacts and management. Malaysian J. Sci. 23:1-42.

Bănărescu P, 1990-1995. Zoogeography of fresh waters 1-3. AULA-Verlag, Wiesbaden: 1617 pp.

Bayly IAE, 1992. The non-marine Centropagidae (Copepoda:
Calanoida) of the world, p. 1-30. In: H.J. Dumont (ed.), Guides to the identification of the microinvertebrates of the continental waters of the world, 2. SPB Academic Publishers.

Beck RMD, Godthelp H, Weisbecker V, Archer M, Hand SJ, 2008. Australia's oldest marsupial fossils and their biogeographical implications. PLoS ONE 3:e1858.

Brehm V, 1937. [Brasilianische Cladoceren, gesammelt von Dr. O. Schubart. Zweiter Bericht]. [Article in German]. Int. Rev. Ges. Hydrobio. 35:497-512.

Brendonck L, De Meester L, 2003. Egg banks in freshwater zooplankton: evolutionary and ecological archives in the sediment. Hydrobiologia 491:65-84.

Briggs JC, 1987. Biogeography and plate tectonics. Dev. Palaeontol. Stratigr. 10:1-204.

Briggs JC, 2004. The ultimate expanding earth hypothesis. J. Biogeogr. 31:855-857.

Brock MA, Nielsen DL, Shiel RJ, Green JD, Langley JD, 2003. Drought and aquatic community resilience:the role of eggs and seed in sediments of temporary wetlands. Freshwater Biol. 48:1207-1218.

Brundin L, 1966. Transantarctic relationships and their significance, as evidenced by the chironomid midges. Kungliga Svenska Vetenskapsakademiens Handlingar 11:1-472.

Cáceres CE, Soluk DA, 2002. Blowing in the wind: a field test of overland dispersal and colonization by aquatic invertebrates. Oecologia 131:402-408.

Chanderbali AS, van der Werff H, Renner SS, 2001. Phylogeny and historical biogeography of Lauraceae: evidence from the chloroplast and nuclear genomes. Ann. Mo. Bot. Gard. 88:104-134.

Chatterjee T, Kotov AA, Van Damme K, Chandrasekhar SVA, Padhye S, 2013. An annotated checklist of the Cladocera (Crustacea: Branchiopoda) from India. Zootaxa 3667:1-89.

Chatterjee S, Scotese CR, 1999. The breakup of Gondwana and the evolution and biogeography of the Indian plate. P. Natl. A. Sci. India A 65:397-425.

Chen X, Huang S, Guo P, Colli GR, Montes de Oca AN, Vitt LJ, Pyron RA, Burbrink FT, 2013. Understanding the formation of ancient intertropical disjunct distributions using Asian and Neotropical hinged-teeth snakes (Sibynophis and Scaphiodontophis: Serpentes: Colubridae). Mol. Phylogenet. Evol. 66:254-261.

Christenhusz MJM, Chase MW, 2013. Biogeographical patterns of plants in the Neotropics - dispersal rather than plate tectonics is most explanatory. Bot. J. Linn. Soc. 171:277-286.

Clayton JW, Soltis PS, Soltis DE, 2009. Recent long-distance dispersal overshadows ancient biogeographical patterns in a pantropical angiosperm family (Simaroubaceae, Sapindales). Syst. Biol. 58:1-16.

Cogger HG, Heatwole H, 1981. The Australian reptiles: origins, biogeography, distribution patterns and island evolution, $\mathrm{p}$. 1332-1373. In: A. Keast (ed.), Ecological biogeography of Australia. Junk.

Cox CB, 1990. New geological theories and old biogeographical problems. J. Biogeogr. 17:117-130.

Cracraft J, 2001. Avian evolution, Gondwana biogeography and the Cretaceous-Tertiary mass extinction event. P. Roy. Soc. Lond. B Bio. 268:459-469.

Cranston PS, 1999. Two unusual Chironomini (Diptera: Chi- 
ronomidae) from Australian rainforest strems: one new genus and a neotropical genus new for the region. Aust. J. Entomol. 38:291-299.

Cranston PS, 2000. Australobrilla Freeman: immature stages, and a new species from the Neotropics. Spixiana 23:101-111.

Cranston PS, Edward DHD, 1999. Botryocladius gen.n.: a new transantarctic genus of orthocladiine midge (Diptera: Chironomidae). Syst. Entomol. 24:305-333.

Cranston PS, Nolte U, 1996. Fissimentum, a new genus of drought-tolerant chironomini (Diptera: Chironomidae) from the Americas and Australia. Entomol. News 107:1-15.

Craw RC, Grehan JR, Heads MJ, 1999. Panbiogeography: tracking the history of Life. Oxford University Press, New York: 229 pp.

Crease TJ, Omilian AR, Costanzo KS, Taylor DJ, 2012. Transcontinental phylogeography of the Daphnia pulex Species Complex. PLoS ONE 7:1-11.

Daday E, 1905. [Untersuchungen über die Süsswasser Mikrofauna Paraguays]. [Article in German]. Cladocera Zoologica 18:1-374.

Davis CC, Bell CD, Mathews S, Donoghue MJ, 2002. Laurasian migration explains Gondwanan disjunctions: evidence from Malpighiaceae. P. Natl. Acad. Sci. USA 99:6833-6837.

Davis CC, Webb CO, Wurdack KJ, Jaramillo CA, Donoghue MJ, 2005. Explosive radiation of Malpighiales supports a Mid-Cretaceous origin of modern tropical rain forests. Am. Nat. 165:e36-65.

De Meester L, Gómez A, Okamura B, Schwenk K, 2002. The monopolization hypothesis and the dispersal-gene flow paradox in aquatic organisms. Acta Oecol. 23:121-135.

Dumont HJ, 1994. On the diversity of the Cladocera in the tropics. Hydrobiologia 272:27-38.

Elías-Gutiérrez M, Kotov AA, Garfias-Espejo T, 2006. Cladocera (Crustacea: Ctenopoda, Anomopoda) from southern Mexico, Belize and northern Guatemala, with some biogeographical notes. Zootaxa 1119:1-27.

Elías-Gutiérrez M, Martínez Jerónimo F, Ivanova NV, ValdezMoreno M, Hebert PDN, 2008. DNA barcodes for Cladocera and Copepoda from Mexico and Guatemala, highlights and new discoveries. Zootaxa 1839:1-42.

Elías-Gutiérrez M, Smirnov NN, Suárez-Morales E, Dimas-Flores N, 2001. New and little known cladocerans (Crustacea: Anomopoda) from southeastern Mexico. Hydrobiologia 442:41-54.

Elías-Guttiérez M, Varela C, 2009. An annotated checklist of the Cladocera of Cuba. Crustaceana 82:1353-1364.

Eskov KY, Golovatch SI, 1986. On the origin of trans-Pacific disjunctions. Zool. Jahrb. Syst. 113:265-285.

Figuerola J, Green AJ, 2002. How frequent is external transport of seeds and invertebrate eggs by waterbirds? A study in Doñana, SW Spain. Arch. Hydrobiol. 155:557-565.

Forró L, Korovchinsky NM, Kotov AA, Petrusek A, 2008. Global diversity of cladocerans (Cladocera: Crustacea) in freshwater. Hydrobiologia 595:177-184.

Frey DG, 1986. The non-cosmopolitanism of chydorid Cladocera: implications for biogeography and evolution, pp. 237256. In: R.H. Gore and K.L. Heck (eds.), Crustacean biogeography. Balkema.

Frey DG, 1987. The taxonomy and biogeography of the Cladocera. Hydrobiologia 145:5-17.
Fryer G, 1968. Evolution and adaptive radiation in the Chydoridae (Crustacea: Cladocera): a study in comparative functional morphology and ecology. Phil. T. R. Soc. Lon. B 254:221-382.

Fryer G, 1972. Observations on the ephippia of certain macrothricid cladocerans. Zool. J. Linn. Soc.-Lond. 41:79-96.

Fryer G, 1987. Morphology and the classification of the socalled Cladocera. Hydrobiologia 145:19-28.

Givnish TJ, Renner SS, 2004. Tropical intercontinental disjunctions: Gondwana breakup, immigration from the Boreotropics, and transoceanic dispersal. Int. J. Plant Sci. 165(Suppl. 4):S1-S6.

Grehan JR, 1991. A panbiogeographic perspective for pre-Cretaceous angiosperm-Lepidoptera evolution. Aust. Syst. Bot. 9:91-110.

Grehan JR, 2007. A brief look at Pacific biogeography: the transoceanic travels of Microseris (Angiosperms: Asteraceae), p. 83-94. In: M. Ebach and R. Tangney (eds.), Biogeography in a changing world. CRC Press.

Güntzel AM, Panarelli EA, da Silva WM, Roche KF, 2010. Influence of connectivity on Cladocera diversity in oxbow lakes in the Taquari River floodplain (MS, Brazil). Acta Limnol. Bras. 22:93-101.

Guo P, Liu Q, Xu Y, Jiang K, Hou M, Ding L, Piron RA, Burbink FT, 2012. Out of Asia: natricine snakes support the Cenozoic Beringian dispersal hypothesis. Mol. Phylogenet. Evol. 63:825-833.

Hackett SJ, Kimball RT, Reddy S, Bowie RCK, Braun EL, Broun MJ, Chojnowski JL, Cox A, Han KL, Harshman J, Huddleston CJ, Marks BD, Miglia KJ, Moore WS, Sheldon FH, Steadman DW, Witt CC, Yur T, 2008. A phylogenomic study of birds reveals their evolutionary history. Science 320:1763-1767.

Havel JE, Medley KA, 2006. Biological invasion across spatial scales: intercontinental, regional, and local dispersal of cladoceran zooplankton. Biol. Invasions 8:459-473.

Heads M, 1999. Vicariance biogeography and terrane tectonics in the South Pacific; analysis of the genus Abrotanella (Compositae). Biol. J. Linn. Soc. 67:391-432.

Hollwedel W, Kotov AA, Brandorff G-O, 2003. Cladocera (Crustacea: Branchiopoda) from the Pantanal (Brazil). Arthropoda Sel. 12:67-93.

Howes G, 1984. Phyletics and biogeography of the aspinine cyprinid fishes. Bull. Br. Mus. Nat. Hist. (Zool.) 47:283-303.

Idris BAG, Fernando CH, 1981. Cladocera of Malaysia and Singapore with new records, redescriptions and remarks on some species. Hydrobiologia 77:233-256.

Kamp PJJ, 1980. Pacifica and New Zealand: proposed eastern elements in Gondwanaland's history. Nature 288:659-664.

Karanovic I, 2008. Three interesting Cyprididae (Ostracoda) from Western Australia. Rec. Aust. Mus. 24:267-287.

Karanovic I, 2012. Recent freshwater Ostracods of the world. Crustacea, Ostracoda, Podocopida. Springer, The Netherlands: 608 pp.

Karanovic T, Eberhard SM, Murdoch A, 2011. A cladistic analysis and taxonomic revision of Australian Metacyclops and Goniocyclops, with description of four new species and three new genera (Copepoda, Cyclopoida). Crustaceana 84:1-67.

Keogh JS, 1998. Molecular phylogeny of elapid snakes and a 
consideration of their biogeographic history. Biol. J. Linn. Soc. 63:177-203.

Keogh JS, Edwards DL, Fisher RN, Harlow PS, 2008. Molecular and morphological analysis of the critically endangered Fijian iguanas reveals cryptic diversity and a complex biogeographic history. Philos. T. Roy. Soc. B 363:3413-3426.

Korovchinsky NM, 2006. The Cladocera (Crustacea: Branchiopoda) as a relict group. Zool. J. Linn. Soc.-Lond. 147:109-124.

Korovchinsky NM, 2011. Description of Sarsilatona cf. fernandoi (Rane, 1983) (Crustacea: Cladocera: Sididae) found in the south of Vietnam. Zootaxa 3129:29-38.

Korovchinsky NM, 2013. Cladocera (Crustacea: Branchiopoda) of South East Asia: history of explorations, taxon richness and notes on zoogeography. J. Limnol. 72(Suppl.2):e7.

Korovchinsky NM, Sanoamuang L, 2008. Overview of Sididae (Crustacea: Cladocera: Ctenopoda) of Northeast and East Thailand, with description of a new species of the genus $D i$ aphanosoma. Zootaxa 1682:45-61.

Korpelainen H, 1986. The effect of diapause on the genetic structure of Daphnia magna populations. J. Zool. Syst. Evol. Res. 24:291-299.

Kotov AA, 2006. Adaptations of Anomopoda crustaceans (Cladocera) the the benthic mode of life. Entomol. Rev. 86(Suppl. 2):S210-S225.

Kotov AA, 2007. Jurassic Cladocera (Crustacea, Branchiopoda) with a description of an extinct Mesozoic order. J. Nat. Hist. 41:13-37.

Kotov AA, 2008. Finding of Pleuroxus smirnovi sp. nov. from the Pamir region revealed today's imperfect state of systematics and biogeography of the Chydorinae (Cladocera: Chydoridae). Int. Rev. Hydrobiol. 93:200-209.

Kotov AA, 2009. New finding of Mesozoic ephippia of the Anomopoda (Crustacea: Cladocera). J. Nat. Hist. 43:523528.

Kotov AA, Hollwedel, 2004. Revision of the Macrothrix paulensis species group (Anomopoda, Cladocera, Branchiopoda) in Neotropics, with description of M. brandorffi n. sp. Arch. Hydrobiol. 151:125-159.

Kotov AA, Ishida S, Taylor DJ, 2009. Revision of the genus Bosmina (Cladocera: Bosminidae), based on evidence from male morphological characters and molecular phylogenies. Zool. J. Linn. Soc.-Lond. 156:1-51.

Kotov AA, Maiphae S, Sanoamuang L, 2005. Revision of Macrothrix paulensis-like species (Anomopoda, Cladocera, Branchiopoda) in Asia, and phylogeny of the paulensisgroup. Arch. Hydrobiol. 151:269-299.

Kotov AA, Taylor DJ, 2011. Mesozoic fossils (>145 Mya) suggest the antiquity of the subgenera of Daphnia and their coevolution with chaoborid predators. BMC Evol. Biol. $11: 129$.

Kotov AA, Van Damme K, Bekker EI, Siboualipha S, Silva-Briano M, Adabache Ortiz A, Galvan de la Rosa R, Sanoamuang L, 2013. Cladocera (Crustacea: Branchiopoda) of Vientiane province and municipality, Laos. J. Limnol 72(Suppl.2):e6.

Lavin M, Herendeen P, Wojciechowski MF, 2005. Evolutionary rates analysis of Leguminosae implicates a rapid diversification of lineages during the Tertiary. Syst. Biol. 54:530-549.

Lavin M, Luckow M, 1993. Origins and relationships of tropical
North America in the context of the boreotropics hypothesis. Am. J. Bot. 80:1-14.

Lewis MH, 1984. The freshwater Harpacticoida of New Zealand: a zoogeographical discussion. Crustaceana 7:305314.

Lewis MH, 1986. Biogeographic trends within the freshwater Canthocamptidae (Harpacticoida). Syllogeus 58:115-125.

Li J, Christophel DC, Conran JG, Li HW, 2004. Phylogenetic relationships within the 'core' Laureae (Litsea complex, Lauraseae) inferred from sequences of the chloroplast gene mat $\mathrm{K}$ and nuclear ribosomal DNA regions. Plant Syst. Evol. 246:19-36.

Li L, Li J, Rohwer JG, van der Werf H, Wang ZH, Li HW, 2011. Molecular phylogenetic analysis of the Persea group (Lauraceae) and its biogeographic implications on the evolution of tropical and subtropical Amphi-Pacific disjunctions. Am. J. Bot. 98:1520-1536.

Lopretto EC, Morrone JJ, 1998. Anaspidacea, Bathynellacea (Crustacea, Syncarida), generalised tracks, and the biogeographical relationships of South America. Zool. Scr. 27:311318.

Löve A, 1967. The evolutionary significance of disjunctions. Taxon 16:324-333.

Maiphae S, Pholpunthin P, Dumont HJ, 2005. Species richness of the Cladocera (Branchiopoda: Anomopoda and Ctenopoda) in southern Thailand, and its complementarity with neighboring regions. Hydrobiologia 537:147-156.

Maiphae S, Pholpunthin P, Dumont HJ, 2008. Taxon richness and biogeography of the Cladocera (Crustacea, Ctenopoda, Anomopoda) of Thailand. Ann. Limnol.-Int. J. Lim. 44:3343.

Makrushin AV, Lianguzova IV, 2006. The shell of invertebrate and plant propagules: selective permeability and barriers. Zh. Obshch. Biol. 67:120-126.

Matile L, 1990. [Recherches sur la systématique et l'évolution des Keroplatidae (Dipstera, Mycetophiloidea)]. [Book in French]. Muséum National d'Histoire Naturelle ed., Paris: $682 \mathrm{pp}$.

McCarthy D, 2003. The trans-Pacific zipper effect: disjunct sister taxa and matching geological outlines that link the Pacific margins. J. Biogeogr. 30:1545-1561.

McCarthy D, 2007. Are plate tectonics explanations for trans-pacific disjunctions plausible? Empirical tests of radical dispersalist theories, p.177-198. In: M.C. Ebach and R. Tangney (eds.), Biogeography in a changing world. CRC Press.

McCarthy D, Ebach MC, Morrone JJ, Parenti LR, 2007. An alternative Gondwana: biota links South America, New Zealand and Australia. Biogeografia 2:2-12.

McKenna MC, 1983. Cenozoic paleography of North Atlantic land bridges, p. 351-395. In: M.H.P. Bott, S. Saxov, M. Talwani and J. Thiede (eds.), Structure and development of the Greenland-Scotland bridge: new concepts and methods. Plenum.

Melville R, 1966. Continental drift, Mesozoic continents and the migrations of the angiosperms. Nature 211:116-120.

Mey W, 1998. The distribution of Apsilochorema Ulmer, 1907: biogeographic evidence for the Mesozoic accretion of a Gondwana microcontinent to Laurasia, p. 91-98. In: R. Hall, and J.D. Holloway (eds.), Biogeography and geological evolution of SE Asia. Backhuys Publ. 
Miller WB, Naranjo-García E, 1991. Familial relationships and biogeography of western American and Caribbean Helicoidea (Mollusca: Gastropoda: Pulmonata). Am. Malacol. Bull. 8:147-153.

Missiaen P, Gingerich PD, 2012. New early Eocene tapiromorph perissodactyls from the Ghazij Formation of Pakistan, with implications for mammalian biochronology in Asia. Acta Palaeontol. Pol. 57:21-34.

Moores EM. 1998. Ophiolites, the Sierra Nevada, "Cordilleria", and orogeny along the Pacific and Caribbean margins of North and South America. Int. Geol. Rev. 40:40-54.

Morley RJ, 2000. Origin and evolution of tropical rain forests. John Wiley and Sons, Chichester: 362 pp.

Morley RJ, 2001. Why are there so many primitive angiosperms in the rain forests of Asia-Australia? p. 185-200. In: I. Metcalfe, B. Smith, M. Morwood and I. Davidson (eds.), Floral and fauna migrations and evolution in SE Asia-Australia. Swetz \& Zeitliner.

Morley RJ, 2013. Cenozoic ecological history of South East Asian peat mires based on comparison of coals with present day and Late Quaternary peats. J. Limnol. 72(Suppl.2):e3.

Morley RJ, Morley HP, 2013. Mid Cenozoic freshwater wetlands of the Sunda region. J. Limnol. 72(Suppl.2):e2.

Morrone JJ, 1996. Austral biogeography and relict weevil taxa (Coleoptera: Nemonychidae, Belidae, Brentidae, and Caridae). J. Comp. Biol. 1:123-127.

Morrone JJ, 2001. Homology, biogeography and areas of endemism. Divers. Distrib. 7:297-300.

Morrone JJ, Crisci JV, 1995. Historical biogeography: introduction to methods. Annu. Rev. Ecol. Syst. 26:373-401.

Nelson G, Ladiges PY, 2001. Gondwana, vicariance biogeography and the New York School revisited. Aust. J. Bot. 49:389409.

Nur A, Ben-Avraham Z, 1977. Lost Pacifica continent. Nature 270:41-43.

Nur A, Ben-Avraham Z, 1982. Oceanic plateaux, the fragmentation of continents and mountain building. J. Geophys. Res. 87:3644-3661.

Penney D, Selden PA, 2005. First fossil Huttoniidae (Arthropoda: Chelicerata: Araneae) in late Cretaceous Canadian amber. Cretaceous Res. 27:442-446.

Penney D, Selden PA, 2011. Fossil spiders: the evolutionary history of a mega-diverse order. Siri Scientific Press, Manchester: $128 \mathrm{pp}$.

Pinto RL, Rocha CEF, Martens K, 2004. On the genus Penthesilenula Rossetti and Martens, 1998 (Crustacea, Ostracoda, Darwinulidae) from (semi-) terrestrial habitats in São Paulo State (Brazil), with the description of a new species. J. Nat. Hist. 38:2567-2589.

Proctor VW, 1964. Viability of crustacean eggs recovered from ducks. Ecology 45:656-658.

Reid JW, Pinto-Coelho RM, 1994. An afro-asian continental copepod, Mesocyclops ogunnus, found in Brazil; with a new key to the species of Mesocyclops in South America and a review of intercontinental introductions of copepods. Limnologica 24:359-368.

Rey J, Vasquez E, 1986a. [Cladocères de quelques corps d'eaux du bassin moyen de l'Orénoque (Vénézuela)]. [Article in French]. Ann. Limnol.-Int. J. Lim. 22:137-168.

Rey J, Vasquez E, 1986b. [Contribution à la connaissance des
Cladocères néotropicaux: redescription de Leydigiopsis ornata Daday, 1905 (Crustacea, Cladocera)]. [Article in French]. Ann. Limnol.-Int. J. Lim. 22:169-176

Ribeiro GC, Eterovic A, 2011. Neat and clear: 700 species of crane flies (Diptera: Tipulomorpha) link southern South America and Australasia. Syst. Entomol. 36:754-767.

Ripley BJ, Hotz J, Simovich MA, 2004. Cyst bank life-history model for a fairy shrimp from ephemeral points. Freshwater Biol. 49:221-231.

Rocha O, Santos-Wisniewski MJ, Matsumura-Tundisi T, 2011. Checklist of fresh-water Cladocera from São Paulo State, Brazil. Biota Neotrop. 11:1-22.

Rocha Sousa FD, Elmoor-Loureiro LM, 2013. Cladocerans (Crustacea: Anomopoda and Ctenopoda) of the Sempre Vivas National Park, Espinhaço Range, Minas Gerais, Brazil. Check List 9:4-8. Available from: http://www.checklist.org.br/getpdf?SL101-12

Rose KD, 2006. The beginning of the age of mammals. John Hopkins University Press, Baltimora: 428 pp.

Rotondo GM, Springer VG, Scott GA, Schlanger SO, 1981. Plate movement and island integration - a possible mechanism in the formation of endemic biotas, with special reference to the Hawaiian Islands. Syst. Zool. 30:12-21.

Sacherová V, Hebert PDN, 2003. The evolutionary history of the Chydoridae (Crustacea: Cladocera). Biol. J. Linn. Soc. 79:629-643.

Sanmartín I, Ronquist F, 2004. Southern Hemisphere biogeography inferred by event-based models: plant versus animal patterns. Syst. Biol. 53:216-243.

Sanoamuang L, 1998. Contributions to the knowledge of the Cladocera of northeast Thailand. Hydrobiologia 362:45-53.

Santos-Wisniewsky MJ, Rocha O, Matsumura-Tundisi T, 2001. First record of Alona setigera Brehm (Cladocera, Chydoridae) in the Neotropical Region. Braz. J. Biol. 61: 701-702.

Sars GO, 1901. Contributions to the knowledge of the freshwater Entomostraca of South America, as shown by artificial hatching from dried material. Arch. Math. Naturvidensk. 23:1-102.

Schabestberger R, Drozdowski G, Rott E, Lenzenweger R, Jersabek CD, Fiers F, Traunspurger W, Reiff N, Stoch F, Kotov AA, Martens K, Schatz H, Kaiser R, 2009. Losing the bounty? Investigating species richness in isolated freshwater ecosystems of Oceania. Pac. Sci. 63:153-179.

Schminke HK, 1974. Mesozoic intercontinental relationships as evidenced by bathynellid Crustacea (Syncarida: Malacostraca). Syst. Zool. 23:157-164.

Schram FR, 2008. Does biogeography have a future in a globalized world with globalized faunas? Contrib. Zool. 77:127133.

Schwentner M, Clavier S, Fritsch M, Olesen J, Padhye S, Timms BV, Richter S, 2013. Cyclestheria hislopi (Crustacea: Branchiopoda): a group of morphologically cryptic species with origins in the Cretaceous. Mol. Phylogenet. Evol. 66:800810.

Scourfield DJ, 1902. The ephippia of the lynceid Entomostraca. J. Queckett Microsc. Club 8:217-244.

Segers H, De Smet WH, 2008. Diversity and endemism in Rotifera: a review, and Keratella Bory de St. Vincent. Biodivers. Conserv. 17:303-316. 
Sequiera AS, Farrell BD, 2001. Evolutionary origins of Gondwanan interactions: how old are Araucaria beetle herbivores. Biol. J. Linn. Soc. 74:459-474.

Serafim M Jr., Lansac-Toha FA, Paggi JC, Velho LFM, Robertson B, 2003. Cladocera fauna composition in a river-lagoon system of the Upper Paraná River floodplain, with a new record for Brazil. Braz. J. Biol. 63:349-356.

Sharma PP, Giribet G, 2012. Out of the Neotropics: Late Cretaceous colonization of Australasia by American arthropods. P. R. Soc. B. 279:3501-3509.

Sharma BK, Sharma S, 2007. New records of two interesting chydorid cladocerans (Branchiopoda: Cladocera: Chydoridae) from floodplain lakes of Assam, India. Zoos. Print Journal 22:2799-2801.

Sharma BK, Sharma S, 2012. Notes on some rare and interesting Cladocera (Crustacea: Branchiopoda: Anomopoda: Chydoridae) from Deepor Beel, Assam, India. J. Threat. Taxa 4:2304-2309.

Sims RW, 1980. A classification and the distribution of earthworms, suborder Lumbricina (Haplotaxida: Oligochaeta). Bull. Br. Mus. Nat. Hist. (Zool.) 39:103-124.

Sinev AY, 1999. Alona costata Sars, 1862 versus related palaeotropical species: the first example of close relations between species with a different number of main head pores among Chydoridae (Crustacea: Anomopoda). Arthropoda Sel. 8:131-148.

Sinev AY, 2004a. Miralona gen. n. - a new genus of the subfamily Aloninae (Anomopoda, Chydoridae) from Australia. Hydrobiologia 526:3-14.

Sinev AY, 2004b. Redescription of two species of the genus Leydigiopsis Sars, 1901 (Branchiopoda, Anomopoda, Chydoridae). Invertebrate Zoology 1:75-92.

Sinev AY, 2008. A new species related to Alona costata Sars, 1862 (Cladocera: Anomopoda: Chydoridae) from South Africa. Zootaxa 1707:23-36.

Sinev AY, 2012. Alona kotovi sp.nov., a new species of Aloninae (Cladocera: Anomopoda: Chydoridae) from South Vietnam. Zootaxa 3475:45-54.

Sinev AY, Elmoor-Loureiro LMA, 2010 Three new species of chydorid cladocerans of subfamily Aloninae (Branchipoda: Anomopoda: Chydoridae) from Brazil. Zootaxa 2390:1-25.

Sinev AY, Korovchinsky NM, 2013. Cladocera (Crustacea: Branchiopoda) of Cat Tien National Park, South Vietnam. J. Limnol. 72(Suppl.2):e8.

Sinev AY, Kotov AA, 2012. New and rare Aloninae (Cladocera: Anomopoda: Chydoridae) from Indochina. Zootaxa 3334:128.

Sinev AY, Sanoamuang L, 2007. Alona siamensis sp. n., a new species of Cladocera from South-East Asia, related to Alona dentifera (Sars, 1901) (Anomopoda: Chydoridae). Arthropoda Sel. 16:143-150.

Sinev AY, Van Damme K, Kotov AA, 2004. Morphology of a Neotropical cladoceran Alona dentifera (Sars, 1901), and its position within the Chydoridae Stebbing, 1902 (Branchiopoda: Anomopoda). Arthropoda Sel. 13:99-107.

Sluys R, 1994. Explanations for biogeographic tracks across the Pacific Ocean: a challenge for paleogeography and historical biogeography. Prog. Phys. Geog. 18:42-58.

Sluys R, 1995. Platyhelminths as paleogeographical indicators. Hydrobiologia 305:49-53.
Smirnov NN, 1971. [Chydoridae of the world. Fauna of the USSR 101]. [Book in Russian]. Nauka, Leningrad: 531 pp.

Smirnov NN, 1988. Cladocera (Crustacea) from Nicaragua. Hydrobiologia 160:63-77.

Smirnov NN, 1995. Check-list of the Australian Cladocera (Crustacea). Arthropoda Sel. 4:3-6.

Smith DJ, Timonen HJ, Jaffe DA, Griffin DW, Birmele MN, Perry KD, Ward PD, Roberts MS, 2013. Intercontinental dispersal of bacteria and archaea by transpacific winds. Appl. Environ. Microb. 79:1134-1139.

Strandberg J, Johanson KA, 2010. The historical biogeography of Apsilochorema (Trichoptera, Hydrobiosidae) revised, following molecular studies. J. Zool. Syst. Evol. Res. 49:110118.

Tanaka S, Ohtaka A, 2010. Freshwater Cladocera (Crustacea, Branchiopoda) in Lake Tonle Sap and its adjacent waters in Cambodia. Limnology 11:171-178.

Tiffney BH, 1985. Perspectives of the origin of the floristic similarity between eastern Asia and eastern North America. J. Arnold Arboretum 66:73-94.

Tiffney BH, Manchester SR, 2001. The use of geological and paleontological evidence in evaluating plant phylogenetic hypotheses in the Northern Hemisphere Tertiary. Int. J. Plant Sci. 162(Suppl. 6):S3-S17.

Townsend TM, Laevitt DH, Reeder TW, 2011. Intercontinental dispersal by a microendemic burrowing reptile. P. R. Soc. B 278:2568-2574.

Tyler MJ, 1979. Herpetofauna relationships of South America with Australia, p. 73-106. In: W.E. Duellman (ed.), The South American herpetofauna: its origin, evolution, and dispersal. Museum of Natural History, University of Kansas ed.

Tyler MJ, Watson GF, Martin AA, 1981. The Amphibia: diversity and distribution, p. 1277-1301. In: A. Keast (ed.), Ecological biogeography of Australia. Junk.

Valdivia Villar RS, 1984. [On the morphology of Neotropical crustaceans of the genus Leydigiopsis (Cladocera, Chydoridae)]. [Article in Russian]. Zool. Zh. 63:1572-1575.

Van Damme K, Bekker EI, Kotov AA, 2013a. Endemism in the Cladocera (Crustacea: Branchiopoda) of Southern Africa. J. Limnol. 72:e36.

Van Damme K, Dumont HJ, 2008a. Further division of Alona Baird, 1843: separation and position of Coronatella Dybowski \& Grochowski and Ovalona gen.n. (Crustacea: Cladocera). Zootaxa 1960:1-44.

Van Damme K, Dumont HJ, 2008b. The 'true' genus Alona Baird, 1843 (Crustacea: Cladocera: Anomopoda): characters of the A. quadrangularis-group and description of a new species from Democratic Republic Congo. Zootaxa 1945:125.

Van Damme K, Dumont HJ, 2010. Cladocera of the Lençóis Maranhenses (NE - Brazil): faunal composition and a reappraisal of Sars' method. Braz. J. Biol. 70:755-779.

Van Damme K, Eggermont H, 2011. The Afromontane Cladocera (Crustacea: Branchiopoda) of the Rwenzori (UgandaD.R. Congo): taxonomy, ecology and biography. Hydrobiologia 676:57-100.

Van Damme K, Kotov AA, Dumont HJ, 2005. Redescription of Leydigia parva Daday, 1905 and assignment to Parvalona gen.nov. (Cladocera: Anomopoda: Chydoridae). J. Nat. Hist. 39:2125-2136. 
Van Damme K, Maiphae S, Sa-ardrit P, 2013b. Inland swamps in South East Asia harbour hidden cladoceran diversities: species richness and the description of new paludal Chydoridae (Crustacea: Branchiopoda: Cladocera) from Southern Thailand. J. Limnol. 72(Suppl.2):e10.

Van Damme K, Shiel RJ, Dumont HJ, 2007. Notothrix halsei gen.n., sp.n., a representative of a new family of freshwater cladocerans (Branchiopoda, Anomopoda) from SW Australia, with a discussion of ancestral traits and a preliminary molecular phylogeny of the order. Zool. Scr. 36:465-487.

Vandekerkhove J, Declerck S, Jeppesen E, Conde-Porcuna JM, Brendonck L, De Meester L, 2005a. Dormant propagule banks integrate spatio-temporal heterogeneity in cladoceran communities. Oecologia 142:109-116.

Vandekerkhove J, Louette G, Brendonck L, De Meester L, 2005b. Development of cladoceran egg banks in new and isolated pools. Arch. Hydrobiol. 162:339-347.

Van der Meutter F, Stoks R, De Meester L, 2008. Size-selective dispersal of Daphnia resting eggs by backswimmers (Notonecta maculata). Biol. Letters 4:494-496.

Vanschoenwinkel B, Pinceel T, Vanhove M, denis C, Jocqué M, Timms B, Brendonck L, 2012. Towards a global phylogeny of the "living fossil" crustacean order of the Notostraca. PLoS One 7:e34998.

van Steenis CGGJ, 1962. Land bridge theory in botany. Blumea 11:235-372

Winterbourn MJ, 1980. The freshwater insects of Australasia and their affinities. Palaeogeogr. Palaeocl. 31:235-249.

Wolfe JA, 1975. Some aspects of plant geography of the Northern Hemisphere during the late Cretaceous and Tertiary. Ann. Mo. Bot. Gard. 62:264-279.

Woodruff DS, 2010. Biogeography and conservation in Southeast Asia: how 2.7 million years of repeated environmental fluctuations affect today's patterns and the future of the remaining refugial-phase biodiversity. Biodivers. Conserv. 19:919-941.

Wyngaard GA, Hołyńska MK, Schulte JA, 2010. Phylogeny of the freshwater copepod Mesocyclops (Crustacea: Cyclopidae) based on combined molecular and morphological data, with notes on biogeography. Mol. Phylogenet. Evol. 55: 753-764.

Zoppi de Roa E, Vasquez W, 1991. Additional records for Mantecal and new for Venezuela. Hydrobiologia 225:45-62. 